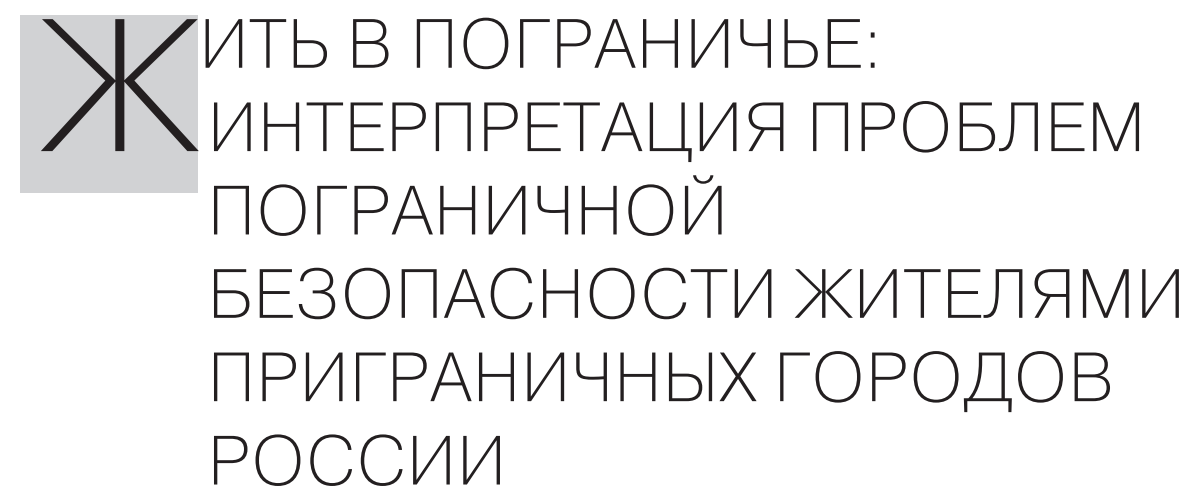

\title{
Ольга Вендина
}

Ольга Вендина, лаборатория геополитических исследований, Институт географии РАН. Адрес для переписки: Старомонетный пер., 29, Москва, 119017, Россия. o.vendina@gmail.com.

Исследование выполнено в Институте географии РАН при финансовой поддержке Российского научного фонда, проект РНФ 14-18-03621 («Российское пограничье: вызовы соседства»); аналитическая часть работы проводилась в рамках бюджетной темы ИГ РАН № 0148-2019-0008 («Проблемы и перспективы территориального развития России в условиях его неравномерности и глобальной нестабильности»).

Автор выражает глубокую признательность Алексею Левинсону, ведущему специалисту Аналитического центра Юрия Левады, за помощь в подготовке и проведении исследования, а также своим коллегам Марии Зотовой и Антону Гриценко, благодаря участию которых в совместном проекте удалось провести большое количество интервью.

Статья основана на материалах полевых исследований и посвящена восприятию проблем безопасности государственной границы жителями малых приграничных городов России. Концептуальной рамкой анализа является теория секьюритизации, предложенная в конце 1990-х годов представителями копенгагенской школы международных исследований и критически переосмысленная в последние два десятилетия. Автор статьи ставил перед собой несколько целей - выявить сходства и различия в обыденном понимании безопасности на разных участках российской границы, показать специфику представлений людей о своей роли в ее обеспечении, предложить возможные объяснения наблюдаемой вариативности, исходя из особенностей локального социокультурного, политического и пространственного контекста. Для сравнительного анализа выбраны города Армянск, Джанкой, Троицк и Забайкальск, расположенные в непосредственной близости от государственной границы. Данный выбор был обусловлен кардинальными отличиями соответствующих участков российской границы: а) непризнанная и конфликтная граница между Россией и Украиной в Крыму; б) открытая граница с Казахстаном на участке в Челябинской области; в) граница с Китаем на участке в Забайкальском крае. В первой части статьи анализируется отношение респондентов к проблеме открытости/за- 
крытости границ в контексте безопасности местной жизни, во второй - рассмотрены факторы, влияющие на мнения людей: такие, например, как этнокультурные стереотипы, контекст жизни (город), восприятие своего и соседнего государства. В заключении обсуждается вызванное различием трактовок безопасности противоречие между приоритетами государства в пограничье и интересами местных жителей.

Ключевые слова: пограничье; государство; национальная безопасность; секьюритизация; малые пограничные города; идентичность; культурная определенность

Идея провести сравнительное исследование восприятия проблем пограничной безопасности жителями малых приграничных городов России возникла в ходе экспедиционной поездки в Крым ранней осенью 2017 года с целью оценить влияние смены государственной юрисдикции региона и блокады Крымского полуострова со стороны Украины на состояние местной экономики и перспективы локального развития. Особое внимание уделялось городам северного Крыма, которые в одночасье превратились из транзитных в тупиковые и из «сельской глубинки» в пограничье.

Наиболее сильные впечатления, вынесенные из этой поездки, были связаны с сохраняющейся остротой переживания событий «крымской весны». Хотя, проводя интервью с представителями власти, бизнеса, экспертами, журналистами и обычными людьми, мы всячески стремились удерживать беседу в рамках социально-экономической повестки, в какой-то момент у наших собеседников на глаза наворачивались слезы, и они рассказывали о пережитых эмоциях, страхах и надеждах. Эта ситуация повторялась из раза в раз. Отличие северного Крыма на этом фоне состояло в рассказе о том, как в условиях полной неопределенности и ожидания «всего самого худшего» (сценарий силового подавления крымского бунта рассматривался как наиболее вероятный) люди отправились на «границу» Крыма и Украины, чтобы, во-первых, обозначить этот рубеж, а во-вторых, защитить его. Профессиональных военных - бойцов крымского подразделения особого назначения «Беркут», вернувшихся к тому моменту из Киева, - в отрядах самообороны было немного, они формировались в основном из местных жителей, имевших опыт службы в армии или владения стрелковым оружием. Вооружены такие отряды были по-любительски, тем не менее ощущение того, что они - единственные защитники всего «своего» - дома, семьи, близких, привычек и жизненных принципов, - заставляло людей преодолевать страх и проявлять смелость. Было похоже, что наши собеседники сами не ожидали от себя такого героизма, ими двигало почти инстинктивное чувство самозащиты, вызванное ощущением надвигавшейся опасности, неважно - реальной или воображаемой.

Ситуацию в Крыму трудно назвать типичной, однако она высветила целый ряд вопросов, общих для российского пограничья. Во-первых, о распространенности представлений о границе как угрозе для местного населения, источнике страхов, проблем и нестабильности. Во-вторых, о смыслах, которые приграничное население вкладывает в понятие «безопасность» и о видении людьми своей роли в ее обеспечении. В-третьих, об условиях формирования повестки безопасности на локальном уровне и о влиянии на жизнь местных сообществ пограничной полити- 
ки, проводимой государством. Ответы на эти вопросы требовали нового исследования. В северном Крыму оно было проведено поздней осенью 2017 года, а на российско-казахстанской и российско-китайской границах - весной и летом 2018-го. Результаты исследования представлены в данной статье. Автор анализирует вопросы восприятия пограничной безопасности жителями малых приграничных городов, политики, проводимой своим и соседним государством, отношений между локальными приграничными сообществами, а также влияния близости границы на настроения людей и оценку ими перспектив собственной жизни.

\section{БЕЗОПАСНОСТЬ ГРАНИЦЫ: «СОСТОЯНИЕ ЗАЩИЩЕННОСТИ» И ЖОЩУЩЕНИЕ УГРОЗЫ»}

Стратегия национальной безопасности РФ (2015) определяет безопасность как «состояние защищенности личности, общества и государства от внутренних и внешних угроз, [...] создающих прямую или косвенную возможность нанесения ущерба национальным интересам» ${ }^{1}$. Национальные интересы - это «объективно значимые потребности личности, общества и государства» в защите и устойчивом развитии. Обеспечение национальной безопасности - функция «органов государственной власти и местного самоуправления во взаимодействии с институтами гражданского общества, которые отвечают за реализацию государственной политики». Приоритеты такой политики многообразны: от упрочения статуса России как «одной из лидирующих мировых держав», укрепления государственного суверенитета, территориальной целостности страны и нерушимости границ до здоровья населения и охраны «традиционных российских духовно-нравственных ценностей». В списке приоритетов фигурирует и повышение конкурентоспособности национальной экономики. Главным направлением обеспечения государственной и общественной безопасности является усиление роли государства как ее гаранта.

В принятой Стратегии отчетливо выражены три идеи. Первая: угрозы безопасности государства и их источники многообразны и не сводятся только к задачам обороны страны. «Враг» может быть и внешним, и внутренним, и даже «не врагом», а противником или, как принято сегодня выражаться, «партнером». Вторая: состояние «незащищенности» возникает из объективно существующих, а не надуманных угроз, что требует реалистичной оценки проблем безопасности. Третья: государство является главным, если не единственным, субъектом политики безопасности, отвечающим за суверенитет, территориальную целостность и оборону страны (нерушимость границ), а также социально-демографическое поведение людей и «брожение» умов. Исходя из этой логики, политика безопасности представляется основой легитимности любых вторжений политической власти в неполитические и далекие от государства сферы жизни общества.

1 Указ президента Российской Федерации от 31 декабря 2015 года № 683 «0 Стратегии национальной безопасности Российской Федерации». Российская газета, 31 декабря 2015 г. https://rg.ru/2015/12/31/nac-bezopasnost-site-dok.html. 
Не менее отчетливо эти мысли выражены в рассуждениях о «пограничной безопасности». Инструментальное определение этого понятия дано в фундаментальном труде «Современная мировая политика» (Богатуров 2010), объединившем под одной обложкой статьи ведущих российских специалистов в сфере международных отношений. В нем подчеркивается, во-первых, дискурсивность категории «безопасность», «приемлемость вкладываемых в нее смыслов для правящей элиты и общественного мнения»; во-вторых, реалистичность, ориентация на защиту от конкретных опасностей (нелегальная миграция, наркотрафик, торговля оружием и людьми) и внешних угроз, предполагающих нарушение пограничного режима и территориальной целостности государства; в-третьих, функциональность, связь с государственными институтами, ответственными за охрану границы и контроль трансграничных потоков (Богатуров 2010:556).

В научной литературе такой подход описывается теорией секьюритизации, выдвинутой представителями копенгагенской школы исследований мира и международных отношений (Buzan, Wæver, and de Wilde 1998). По словам создателей, она возникла как реакция на беспрецедентное расширение смыслов, вкладываемых в понятие «безопасность», и его выведение за пределы военной науки и стратегических исследований. Экспансия «безопасности» в сферу экономики, демографии, экологии, культуры и социальной жизни поставила вопрос о механизмах политизации неполитических вопросов, их интерпретации в качестве проблемы национального уровня и дальнейшей секьюритизации со стороны государства. Авторы концепции полагают, что таким механизмом является выведение вопросов, волнующих общество, за рамки нормативной политики в область чрезвычайных ситуаций и экзистенциальных угроз. При этом политизация неполитических проблем зависит не столько от их реального значения для жизни общества (часто они могут находиться на периферии общественного сознания), сколько от их преподнесения как угрозы и восприятия в этом качестве целевой аудиторией. Требование незамедлительного реагирования отменяет обычный процесс публичных обсуждений, наделяет принимаемые решения смыслом «объективно необходимых» и переводит вопросы обеспечения безопасности в сферу технологий и управления рисками (Huysmans 2004). Преодолеть эту ситуацию позволяет возвращение проблем безопасности в сферу нормативной политики, обеспеченной законодательством и политическими процедурами. Авторы намечают этот путь, предлагая классификацию угроз в зависимости от затрагиваемых сфер жизни общества и социально-пространственного уровня агентов безопасности: от государств и их международных альянсов до групп и индивидов.

Теория секьюритизации вызвала заметный отклик в академической среде (Макарычев 2008; Морозов 2011). Практически сразу появились работы, как развивающие ее основные положения (Guzzini and Jung 2003; Stritzel 2007; Buzan and Hansen 2009; Manners 2013), так и подвергающие используемые подходы критическому анализу (C. A. S. E. Collective 2006; McDonald 2008; Balzacq 2005, 2010; Balzacq, Léonard, and Ruzicka 2016). Копенгагенская школа повлияла и на пограничные исследования. Во-первых, ее положения резонировали с идеями критической геополитики (Ó Tauthail 1996; Campbell 1998) о сконструированной приро- 
де представлений о странах, территориях, местах, границах и прочем и ключевом значении дискурс-анализа для понимания внутренних мотивов проводимой политики. Это создало концептуальную основу исследований связи дискурсов, производимых разными агентами общественного влияния (политиками, учеными, журналистами, писателями, гражданскими активистами и др.), с конкретной практикой функционирования границ (Newman and Paasi 1998; Paasi 1999; Salter and Piché 2011; Laine, Liikanen, and Scott 2018). Яркий пример - исследования секьюритизации внешнего периметра Евросоюза по мере расширения зоны действия Шенгенского соглашения² (Bigo 2000; Rumelili 2004; Laine 2007; Van Houtum and Pijpers 2007; Scott and Van Houtum 2009) и смягчения пограничного режима между Россией и Китаем в результате разворота российской политики «на восток» (Колосов и др. 2018а, 20186).

Во-вторых, теория секьюритизации подтолкнула к критическому пересмотру ключевых для политической географии понятий, таких как суверенитет, территориальность государства и границы. Было показано, что суверенитет может быть неполным, условным, дезагрегированным, гибридным, де-факто и де-юро (Biersteker and Weber 1996; Elden 2006; Agnew 2009; Fregonese 2012), территориальность государства может не совпадать с его границами или быть вовсе экстерриториальной (Agnew 2005), а границы рассматриваться как процессы, практики, символы, дискурсы, сети и институты, быть мобильными и динамичными (Бредникова и Воронков 1999; Balibar 2009; Johnson et al. 2011; Amilhat-Szary and Giraut 2015; Konrad 2015). Деконструкция этих базовых понятий поставила под сомнение возможность возвращения политики секьюритизации в нормативное русло, поскольку представления о «референтных объектах» безопасности (Buzan et al. 1998:36) утратили определенность. По мнению Тьерри Балзака (Balzacq 2010), теория секьюритизации была низведена до уровня «совокупности практик», а агенты обеспечения национальной безопасности лишились ареола защитников суверенитета, территориальной целостности и нерушимости границ.

В-третьих, значительное развитие получили исследования, авторы которых обращали внимание на противоречие между безопасностью государства и безопасностью людей (Walker 1990; Dillon and Neal 2008): чем острее стоит вопрос защиты государственного суверенитета и границ, тем меньше безопасности у населения. Разворот в сторону интересов человека требовал деполитизации проблем, связанных с пограничной безопасностью, и превращения пограничья в пространство диалога, интеграции, сотрудничества и добрососедства. Не будет преувеличением сказать, что с середины 1990-х годов до середины 2000-х эта логика преобладала, и трансграничные взаимодействия рассматривались как магистральный путь для устранения межгосударственных противоречий, преодоления экономической периферийности приграничных районов и неравенства соци-

2 В 2005 г. начала функционировать Служба обеспечения безопасности внешних границ EC (FRONTEX), первоначально ориентированная на координацию действий национальных пограничных служб. Миграционный кризис 2015-2016 годов привел к ее реорганизации в Европейское агентство пограничной и береговой службы с расширенными полномочиями по регулированию миграционных потоков и предотвращению пограничных рисков. 
альных возможностей. Этой теме посвящено огромное количество публикаций как в российских, так и зарубежных журналах 3 . Их авторы, не отрицая влияния политизированных дискурсов на жизнь общества в целом и приграничного населения в особенности, сходилось во мнении, что конкретные практики повседневной жизни имеют не меньшее значение для обеспечения безопасности, чем политика, вырабатываемая в столицах. Они способствуют сближению позиций сторон, росту взаимного доверия, преодолению дистанции между «своими» и «чужими», снижению риска конфликтных ситуаций.

Исследования повседневной жизни пограничья выявили перформативную роль неформальных институтов, сообществ и индивидов в установлении, поддержании и модификации режима границ (Бредникова 2008; Ткач 2010; Колосов и Вендина 2011; Бийе 2014; Колосов 2018; Brunet-Jailly 2007; Paasi and Prokkola 2008; Rumford 2008; Zhurzhenko 2010; Parker and Vaughan-Williams 2012; Brambilla et al. 2015). Однако они обнаружили и факты, противоречащие установкам на взаимодействие и сотрудничество. Вопреки преимуществам открытости границ многие жители пограничья, как минимум в России, поддерживали сохранение режима пограничных зон (Колосов и Володин 2016; Зотова, Гриценко и Себенцов 2018). Люди предпочитали «состояние защищенности», как написано в российской Стратегии национальной безопасности, наличию потенциальных преимуществ трансграничных взаимодействий. Разрастание аппарата таможенного и пограничного контроля рассматривалось как ресурс обеспечения занятости и стабильных доходов, а не ограничение. Нередко приводились и аргументы в пользу защиты своей идентичности и образа жизни от нежелательных внешних воздействий или значимости границ для формирования локальных идентичностей (Andersen 2013).

Миграционный кризис в Европе актуализировал эти тезисы и показал, что модель обеспечения безопасности через интеграцию и сотрудничество, несмотря на свою привлекательность, не обладает достаточной эффективностью во внештатных ситуациях. В фокусе внимания вновь оказалась роль границ как важнейшего регулятора не только межгосударственных, но и социальных взаимодействий (Paul et al. 2017; Prokkola 2018). Дебаты о пограничной безопасности вернули теорию секьюритизации в поле публичных обсуждений и потребовали уточнения ее положений с позиции многосубъектности отношений безопасности, множественности идентичностей и необходимости поддержания социально-антропологических и политических границ для мирного сосуществования различий (Коллиер 2016; Vaughan-Williams 2015; Prokkola 2018).

Это отразилось и на риторике политиков - от высказываний Ангелы Меркель о «культуре немецкого гостеприимства» $(2015)^{4}$ до заявления Эммануэля Макрона

3 См., например, публикации, цитируемые в данной статье (Хвощев 2001; Голунов 2002; Вендина и Колосов 2007; Рыжова и Симутина 2007; Бредникова 2008; Paasi 1999; Brunet-Jailly 2007; Laine 2007).

4 "Angela Merkel über Willkommenskultur und gottgegebene Flüchtlingswelle. Interview mit dem Deutschlandfunk vom 04.10.2015," загружено 5 октября 2015 г., видео, 24:26. https://www. youtube.com/watch?v=jUhcycQ6xh4. 
о его вере в «суверенную Европу» и «открытый патриотизм» (2019)5. Яркими моментами выступления Макрона были рассуждения о миграционной политике как важнейшей «битве» Европейского союза, необходимости ужесточения пограничного режима для реализации возможности «гостеприимства» и самого существования демократической Европы. Это не только проиллюстрировало центральные положения теории секьюритизации, но и поразительным образом сблизило российское и западноевропейское понимание безопасности. Официозная «секьюритизаторская» концептуализация пограничных проблем, свойственная российским властям, обрела смысл «правильного» курса, поддерживаемого лидерами ведущих мировых держав.

В этих условиях вопрос о противоречии между интересами государства и людей в пограничье вновь обретает актуальность. Поэтому в данной статье предпринимается попытка проанализировать восприятие проблемы безопасности границ жителями малых приграничных городов России, понять, что для них означает «состояние защищенности», и в чем они видят угрозы. Цель статьи - выявить сходство и различия в обыденном понимании безопасности на разных участках российской границы, показать специфику представлений людей о своей роли в ее обеспечении, предложить возможные объяснения наблюдаемой вариативности, исходя из особенностей локального социокультурного, политического и пространственного контекста. Автор концентрирует внимание на нескольких примерах, что позволяет обеспечить детальный анализ каждого случая и возможность совмещения количественной (социально-экономическая и демографическая статистика, ведомственные данные) и качественной (мнения людей, экспертов, высказывания политиков и прочее) информации. (равнение полученных результатов дает возможность более широких обобщений, релевантных для российского пограничья в целом (Creswell 2014).

\section{ВЫБОР МЕСТ ПРОВЕДЕНИЯ ИССЛЕДОВАНИЯ}

Сравнительные исследования предполагают, с одной стороны, относительное сходство характеристик сравниваемых объектов, а с другой - различие условий их существования. Первоначальный интерес к сложной и неоднозначной ситуации в Крыму предопределил и набор сходных признаков для сравниваемых городов: наиболее общими из них были численность населения (малый или средний город), местоположение (близость к границе) и транзитность. Этим условиям отвечали северокрымские города Джанкой (38 тыс. жителей) и Армянск (22 тыс.), город Троицк (75 тыс.), расположенный в Челябинской области на границе с Казахстаном, и поселок Забайкальск (13 тыс.) - на границе с Китаем. Все выбранные города - важнейшие торговые и транзитные центры своих регионов. Самый маленький из них - Забайкальск - одновременно является наиболее востребованным пограничным пунктом пропуска: ежегодно через него проходит порядка мил-

5 “Immigration: Emmanuel Macron souhaite repenser l'espace Schengen," BFM TV, загружено 25 апреля 2019 г., видео, 1:34. http://www.bfmtv.com/mediaplayer/video/immigrationemmanuel-macron-souhaite-repenser-l-espace-schengen-1156939.html. 
лиона человек, это также одна из крупнейших в России станций по перевалке контейнерных грузов и круглого леса. Различия между городами определялись их историей, структурой хозяйства и генезисом границы.

Новый участок российско-украинской границы в Крыму - результат конфликта. Будучи границей де-факто, она не признается в качестве государственной ни в Украине, ни в мире ${ }^{6}$, тем не менее функционирует как межгосударственная: с ее обеих сторон соблюдаются соответствующие нормы и процедуры. Здесь действует безвизовый режим, однако обе стороны чинят препятствия для свободного перемещения населения и товаров.

Несмотря на «молодость» крымской границы, ее появление не воспринимается местным населением как навязанный факт. Физическое и символическое наличие границы между Крымом и Украиной ощущалось крымчанами и ранее, что подтверждается многими опросами и опытом борьбы за фактическую, а не номинальную автономию Крыма. Метафора писателя Василия Аксенова «остров Крым» была не только популярной на полуострове, но и служила опорой региональной идентичности (Лантух 2012). В общественном сознании крымская граница рисовалась как «естественный рубеж» (Сень 2008; Горюнова 2012). Приводимые в пользу этого аргументы усиливались упоминанием о многочисленных фортификационных сооружениях (таких как Турецкий вал), ставших «второй природой». С точки зрения крымских экспертов, «естественная матрица пространства» (Каганский 2000) предопределяла ход истории, включая создание Крымской АССР в 1921 году․ Тогда крымская граница разделила бывшую Таврическую губернию между Украинской ССР и РСФСР (Шевчук 2006; Бельский 2009). Одним из следствий совмещения политической границы с природным рубежом стало укрепление представлений об отделенности и отдельности полуострова, его слабой связи с «материком» (Задорин 2018). Города Джанкой и Армянск, расположенные на торговых путях, пересекающих единое культурное пространство причерноморских степей, обрели статус и значение фронтирных (Рибер 2004; Billington and Ridge 1982).

Несмотря на небольшую удаленность городов друг от друга и наличие соединяющей их автодороги, они слабо связаны между собой. Причина - значительные различия контекста городской жизни. Джанкой - типичный степной одноэтаж-

6 Факт вхождения Крыма в состав России официально признали Афганистан, Венесуэла, Куба, Никарагуа, Сирия и Северная Корея. Еще 15 стран воздержались при голосовании за резолюцию 00Н в поддержку суверенитета Украины, в их числе Китай, Индия и Иран, а также страны-партнеры России по ЕАЭС.

7 Крымская Автономная ССР была создана в октябре 1921 года в составе РСФСР. В 1945 году после депортации крымских татар, болгар, греков и других народов Крыма республика была упразднена и образована Крымская область. В 1954 году Указом Президиума Верховного Совета СССР область была передана из РСФСР в состав Украинской ССР. В январе 1991 года по результатам референдума Крым восстановил статус республики, но уже без определения «автономная». Крымские элиты претендовали на подписание нового Союзного договора наравне с другими республиканскими субъектами СССР. После распада Советского Союза Крым оставался в составе независимой Украины, но в республике были сильны ирредентистские настроения (Попов 2012). 
ный городок, пыльный, выжженный солнцем и разделенный надвое железной дорогой. Местная промышленность, успешно функционировавшая в советские годы, ушла в небытие, подавляющая часть предприятий закрылась. Рынок труда сжался, город постепенно приходил в упадок, а люди выживали за счет «купли-продажи» и торговли на станции, обеспечивая едой и фруктами пассажиров проходящих поездов. Смена государственной юрисдикции Крыма в 2014 году оборвала инерционный тренд эволюции Джанкоя. Транспортная блокада полуострова со стороны Украины превратила транзитный железнодорожный узел в тупик и еще больше сократила возможности заработков населения. Одновременно в городе появилось много военных, обеспечивающих выполнение пограничных функций. Резко вырос спрос на жилье, что оживило жилищное строительство: впервые за четверть века было построено несколько многоэтажных жилых домов. Город вышел из сонного забытья, семьи военных привнесли новые стандарты потребления, запрос на городское благоустройство и развитие сферы услуг. После длительного застоя в Джанкое забрезжили надежды на развитие.

Армянск ничем не напоминает Джанкой. Это образцовый социалистический город - компактный, благоустроенный и прекрасно распланированный, с улицами-аллеями, рядами многоэтажных домов и зелеными дворами, обеспечивающий трудовыми ресурсами крупнейшее в Крыму предприятие «Крымский титан». Как во всяком моногороде, благополучие его жителей целиком зависит от благополучия завода. Поскольку его продукция, ориентированная на экспорт, была востребована, «Крымский титан» успешно функционировал в постсоветский период, прошел частичную модернизацию, а его работники уверенно смотрели в будущее. После событий 2014 года предприятие столкнулось с колоссальными проблемами из-за блокады полуострова и введения санкций. Резкий спад производства и четырехкратное сокращение выручки привели к значительному снижению заработной платы, задержкам с ее выплатой, длительным простоям предприятия и увольнениям. Город впал в уныние. Навалились экологические проблемы, связанные с перекрытием Северо-Крымского канала и дефицитом воды, а возникшая рядом граница стала восприниматься как угроза существованию завода и города.

Описанные различия траекторий постсоветского развития Джанкоя и Армянска, а главное - разница в настроениях их жителей после присоединения Крыма к России, не позволяют ни объединить оба города в «общий случай», ни отказаться от одного из них ради равновесной композиции исследования по принципу «один город - одна граница». Эти два примера дополняют друг друга, расширяя спектр угроз, ощущаемых населением, и позволяя лучше понять особенности восприятия границы в условиях переживаемой драмы разрыва экономических и социальных связей, транспортной и водной блокады, враждебности межгосударственных отношений.

Российско-казахстанская граница возникла в результате преобразования административной границы между РСФСР и Казахской ССР в межгосударственную после распада СССР в 1991 году. В данном случае был реализован принцип международного права, известный как uti possidetis, предполагающий, что при обретении независимости бывшие колонии или административные единицы 
других государств сохраняют свои территории и границы. Как линия на карте российско-казахстанская граница появилась только в 1936 году при образовании Казахской ССР и затем неоднократно меняла свои очертания, исходя из хозяйственных соображений. Начиная с 1950-х годов законодательные акты об изменении границы стали сопровождаться ее описаниями, мало отличающимся от принятых в практике международных отношений (Голунов 2005). Окончательная делимитация границы произошла только в постсоветские годы. Несмотря на сравнительную «молодость» российско-казахстанской границы, на участке в Челябинской области она имеет более давнюю историю, связанную со строительством Оренбургской укрепленной линии в XVIII веке, которая частично проходила по реке Уй. Ее русло и сегодня отделяет Россию от Казахстана. Помимо пугачевского восстания (1773-1775), в этих местах никогда не было значительных вооруженных конфликтов, для этой территория было характерно мирное взаимодействие живущих здесь народов: казахов, русских, татар и башкир. Сегодня российско-казахстанская граница, как внутренняя граница Евразийского экономического союза (ЕАЭС), является открытой. Она проходит по слабозаселенным степям, где практически отсутствуют пограничные сооружения. На пунктах пропуска осуществляется только паспортный контроль, таможенные проверки минимизированы, а визового режима никогда не было (Голунов 2002; Морачевская и Карпенко 2018).

Город Троицк, расположенный на российской границе, возник как крепость в 1743 году. Его сторожевые функции довольно быстро уступили место торговым, и он превратился в ключевой перекресток торговых путей, соединявших Россию со Средней Азией, Персией и Китаем. Местное население хорошо помнит о «великом прошлом» города. Эта память является базисом местного патриотизма: Троицком гордятся все его жители - и русские, и татары, и казахи, - считая его «своим». Центральные функции Троицка еще более усилились в советское время. Этому способствовали эвакуация предприятий из западных регионов страны в годы Великой Отечественной войны, а позднее - освоение целины. Роль центра, выполняемая городом, повлияла и на принятие решения о строительстве здесь крупнейшей на Южном Урале ГРЭС. Распад СССР кардинально изменил ситуацию: для современного Троицка характерна обвальная деиндустриализация, острый дефицит развития и отток населения. Процесс периферизации города идет одновременно с нарастанием культурной контрастности российско-казахстанского пограничья (Герасименко и Филимонова 2011; Герасименко 2016), размежевания двух стран и постепенного расхождения их внешнеполитических ориентиров. Поэтому в случае Троицка наибольший интерес представлял вопрос о влиянии на восприятие безопасности фактора деградации экономического, социального и культурного потенциала города.

Забайкальский участок российско-китайской границы, в отличие от крымского и казахстанского, является «старейшим» в российском пограничье. Зоны российского и китайского влияния были разделены в этих местах еще Нерчинским договором 1689 года. Конфигурация забайкальской границы несколько раз уточнялась серией последующих договоров, но ее наличие никогда не оспаривалось. 
Это не значит, что здесь не было конфликтов - напротив, они были многочисленными, но преимущественно локальными. Наиболее крупный из них - вооруженный конфликт на Китайско-Восточной железной дороге (КВЖД) в 1929 году. Одним из его результатом стало появление станции «Отпор», ныне известной как «Забайкальск». Смена названия произошла в 1958 году в период «нерушимой» российско-китайской дружбы. Несмотря на то, что линия границы на рассматриваемом участке практически не менялась, отношение к этой границе как зоне кооперации, потенциальной экспансии или барьеру было подвержено циклическим изменениям. Последние два десятилетия советской власти она рассматривалась исключительно с позиции «внешней угрозы» и «стратегического значения» (Ларин 2002). В постсоветские годы закрытая прежде граница открылась, были отменены многочисленные ограничения, включая пропускной режим и запрет на передвижение населения в пограничной зоне. Начались активные трансграничные взаимодействия (Ларин 2008), расцвела приграничная торговля (Рыжова и Симутина 2007). Сегодня российско-китайские отношения переживают один из лучших периодов своей истории. Тем не менее, на границе действует достаточно строгий контроль, который смягчается упрощенным порядком получения виз и наличием системы правил, облегчающих трансграничные перемещения местного населения.

Среди сравниваемых участков российской границы китайский является наиболее контрастным в этническом, культурном и экономическом отношении. Российский приграничный поселок Забайкальск, возникший как военный гарнизон, соседствует с китайским городом Маньчжурия (250 тыс. жителей): расстояние между двумя станциями КВЖД составляет менее десяти километров. Судьбы обоих населенных пунктов тесно связаны: оба были вовлечены в события российской и китайской революций, затем во Вторую мировую войну, пережили времена братства и вражды советского и китайского коммунистических режимов. В постсоветские годы симбиоз Забайкальска и Маньчжурии стал символом челночной торговли, а в последнее время «поворота на восток» российской внешней политики.

Несмотря на сходство экономико-географического положения, траектории развития этих двух городов в постсоветские годы различны. С отменой советского режима погранзоны налаженная и регламентированная жизнь Забайкальска рухнула. Поселок погрузился в пучину хаоса и буквального разбоя. В 1992-1995 годах он прославился грабежами поездов, в которых участвовали и местные жители, и многочисленные приезжие из соседних городов и районов. Далеко не все забайкальцы оказались готовы к такому повороту событий, вместе с отводом войск начался массовый отток местного населения. Одновременно, как «ворота» в Китай и активно работающий пограничный пункт пропуска, поселок стал привлекать новых жителей из соседних районов Забайкальского края, появились и выходцы из других российских регионов и бывших советских республик, прежде всего - из стран Южного Кавказа (Армения, Азербайджан), а также Китая - члены смешанных российско-китайских семей и наемные работники. Пришло понимание, что граница - это не только опасность, долг и ответственность, но и выгода. Началась эпоха теневой коммерческой деятельности - от торговли ширпотребом до вывоза 
круглого леса и контрабанды драгметаллов. С этого времени таможня в глазах людей обрела большее значение, чем пограничная служба.

Под влиянием этих процессов и наметившегося роста численности населения стала меняться городская среда поселка. Была модернизирована вся транспортная инфраструктура, построен крупнейший на российско-китайской границе контейнерный терминал, оборудованы международные пункты пропуска. Выросли и новые жилые кварталы. Частично обновилась социальная инфраструктура, появились гостиницы, отвечающие современным стандартам, кафе и рестораны. Забайкальск сегодня поражает контрастом между убогой общественной средой города, унаследованной от гарнизонного прошлого, и явными знаками личного благополучия довольно значительной группы населения. Но все эти изменения бледнеют на фоне соседней Маньчжурии. Еще недавно ничем не примечательный китайский поселок извлек максимальные выгоды из своего приграничного положения и полутеневой торговли с Россией. Город превратился в ярмарку китайских товаров, ориентированных на российского потребителя, и российских - на китайского. Полутеневой вывоз древесины из России способствовал становлению здесь деревообработки и производства мебели. Маньчжурия выросла вверх и вширь, засияла иллюминацией. Визуальной доминантой города стали небоскребы и гигантская ярко раскрашенная декорация России - отдельно построенный город матрешек, куполов и псевдоцарских дворцов, который «населяют» уменьшенные копии известных советских памятников. Для приезжающих из Забайкальска после собственной серой жизни все это выглядит как цветное кино и вызывает острое недовольство собственным положением. Расцвет Маньчжурии, географическое положение которой ничем не отличается от Забайкальска - те же природа и климат, та же периферийность по отношению к столице государства, общая история КВЖД, - создает у забайкальцев ощущение упущенных возможностей, которыми с успехом воспользовались соседи. Эта неоднозначная ситуация делает Забайкальск идеальным местом для исследования отношения людей к безопасности границы в условиях неблагоприятного сравнения себя с соседями.

\section{МЕТОДЫ ИССЛЕДОВАНИЯ}

Вопросы пограничной безопасности относятся к сфере общих и/или коллективных интересов, поэтому основным для исследования стал метод фокус-групп (групповых дискуссий), который при сравнительно небольшой численности респондентов позволяет получать аналог коллективного мнения (Stewart, Shamdasani, and Rook 2009). В тех случаях, когда невозможно было соблюсти необходимые для проведения фокус-групп требования: собрать не знакомых друг с другом людей, как, например, в Забайкальске - самом маленьком из выбранных городов исследования, - использовались приемы и правила проведения открытых групповых дискуссий (open-ended group discussion). Их ключевое отличие от фокус-групп состоит в меньшей формализованности и в силу этого большей гибкости и адаптивности как к составу респондентов, так и к нестандартным условиям общения с ними (Левинсон 2007; Gibbs 1997). Данный метод требует высокого 
профессионализма от модератора, понимания сути происходящей дискуссии, умения сосредоточить внимание респондентов на высказываниях, являющихся важными для проводимого исследования ${ }^{8}$.

Вместе с тем преимущества фокус-групп и их модификаций связаны с определенными ограничениями. Наиболее существенным является недостаточная откровенность респондентов. Публичное обсуждение острых вопросов может препятствовать выражению собственной точки зрения. Особенно отчетливо это проявляется в случае открытых групповых дискуссий. Знакомство людей друг с другом приводит к тому, что в ходе дискуссии часть респондентов занимает пассивную позицию, соглашаясь с высказываниями лидеров, перетягивающих внимание на себя. Замалчиваемые мнения, не фигурирующие в дискуссии, могут быть, однако, очень значимыми для понимания изучаемого вопроса. Поэтому материалы фокус-групп были дополнены индивидуальными интервью. Они проводились с лицами, которые заведомо могли отказаться от участия в групповых дискуссиях и/или хранить молчание, опасаясь последствий своей откровенности. В Крыму это были представители крымско-татарского и украинского меньшинств. В Троицке - «патриоты» города, с подозрением относящиеся к любым внешним инициативам, а также члены татарской и казахской общин. В Забайкальске основное внимание было уделено смешанным российско-китайским семьям, как правило, вовлеченным в местный бизнес, и представителям армянской и азербайджанской диаспор. В исследовании также использовались любые возможности неформального общения - с местными таксистами (переезды иногда занимали значительное время), работниками гостиниц и посетителями кафе, продавцами на рынках и в магазинах, людьми, вместе с которыми приходилось проходить пограничный досмотр. Отдельный блок интервью был проведен с местными экспертами, хорошо знающими жизнь своего города и его проблемы - музейными работниками, включая крымско-татарские музеи и городские самодеятельные музеи, общественниками, журналистами местных газет и радиостанций, преподавателями и исследователями из местных университетов. Также интервьюировались руководящие работники региональных и муниципальных администраций, начальники и специалисты различных департаментов, отвечающих за вопросы экономического и социального развития, миграционных, пограничных, таможенных и консульских служб, работники торгово-промышленных палат. В общей сложности на каждом участке границы было проведено от 25 до 30 интервью. Все проведенные беседы фиксировались и впоследствии транскрибировались. Однако в данной статье этот внушительный массив информации является вспомогательным материалом, обеспечивающим погруженность в локальные проблемы и позволяющим разделять индивидуальные и групповые мнения при интерпретации результатов фокус-групп.

Акцент на коллективном понимании безопасности потребовал особенно внимательного отношения к составу участников фокус-групп. Приступая к рекрутированию респондентов, мы исходили из того, что близость границы затрагивает всех

8 Модератором фокус-групп в городах Троицк и Забайкальск выступал Алексей Левинсон, а в Армянске и Джанкое - Ольга Рямбова, имеющая опыт маркетинговых исследований в Крыму. 
местных жителей. Даже если человек не участвует в трансграничных перемещениях, обменах и коммуникациях, он все равно вовлечен в жизнь границы через своих родных, друзей и знакомых, покупки на рынках и в магазинах, моду, представления, слухи, страхи и ожидания. Поэтому при выборе респондентов мы ориентировались на наиболее представительные группы городского населения, а не на тех, чья деятельность была непосредственно связана с границей.

Мы также полагали, что значительная часть жителей малых городов принимает пассивное участие в трансграничных процессах и отличается низкой мобильностью. Вместе с тем многие из них - старожилы, носители локальной идентичности и представлений о том, «как было» и «как стало». Поэтому большое внимание уделялось тем возрастным когортам, которые в этих малых городах наиболее многочисленны. Самую представительную группу респондентов составляла экономически активная часть жителей в возрасте 30-50 лет. Учитывалось, что занятость в различных сферах деятельности, различия в доходах и круг общения, а также этническая принадлежность накладывают отпечаток на мировоззрение, жизненную позицию и активность людей. Молодежь студенческого возраста нас интересовала меньше. Несмотря на то, что именно с молодежью связываются представления о будущем и об изменении прежнего социального порядка, в малых и средних городах эта группа малочисленна. К тому же большинство вчерашних школьников уезжает учиться в более крупные центры и часто не возвращается назад (Мкртчян 2017).

Набор респондентов производился профессиональными рекрутерами с использованием метода «снежного кома» и отбором участников фокус-групп на второй ступени. Анкетные данные (пол, возраст, место жительства и т. д.) потенциальных респондентов проходили скрининг, в соответствии с предложенными критериями отбора. В ходе работы активно использовались проективные методики: стандартные методы ассоциативных рядов, метафоризации, семантической атрибуции и пр. Основное внимание уделялось выявлению опыта взаимодействий человека со своим городом, страной, соседним государством и населяющими его людьми (этносами), выяснению знания окружающего мира, отношения к границе и ее режиму, опасностям и выгодам приграничного положения.

Материалом, позволившим оценить влияние локального контекста жизни людей на восприятие границы, послужили результаты тестов «Дефиниции мест проживания» (ДЕМП) и «Семантической атрибуции» (СЕМАТ), полученные в ходе фокус-групп ${ }^{9}$. Оба теста содержат элементы количественной оценки и даже при малом размере групп позволяют выявлять структурные различия коллективных представлений. Тест ДЕМП - упражнение на ассоциации: респонденту предлагалось одним словом охарактеризовать свой город или страну. Тест построен таким образом, чтобы стимулировать разнообразие высказываний людей, используя их стремление создать наиболее объемное описание объекта обсуждения. Тест CEMAT - модификация семантического дифференциала Чарльза Осгуда (Osgood, Suci, and Tannenbaum 1961) - базируется на использовании предикатов-антони-

9 Тесты ДЕМП и СЕМАТ - авторские методики Алексея Левинсона, разработанные в Аналитическом центре Юрия Левады. 
мов для характеристики кого-либо или чего-либо. Целью этой групповой игры было выявление отношения жителей приграничных городов к русским и другим этносам, находящимся с ними в тесном контакте. При проведении теста влияние социального окружения на ответы респондентов было минимизировано, сам тест имел характер тайного голосования. Участники получали возможность познакомиться с его результатами только в конце дискуссии и оценить их соответствие своим представлениям. Оба теста показали свою эффективность при ответе на три важных вопроса: 1) влияют ли этнокультурные стереотипы на ощущение опасности/безопасности границы; 2) является ли наделение границы конфликтными свойствами проекцией неудовлетворенности собственной жизнью и ситуацией в городе; 3) в какой мере жители пограничья ощущают свое единство со страной.

Разработанная программа исследования была реализована во всех выбранных городах. Количество фокус-групп зависело от численности населения города и рода занятий его жителей. В Джанкое было проведено четыре фокус-группы (ФГ): ФГ1 - с пенсионерами (составляющими более трети населения), которые пережили все этапы истории города с 1970-х годов; ФГ2 - с работниками бюджетной сферы, имеющими опыт общения с украинским и российским государством; ФГ3 - с местными самозанятыми и предпринимателями; ФГ4 - с украинцами и крымскими татарами, как представителями этнических групп, в отношении которых существует мнение о неприятии ими событий «крымской весны». Решение о смешанном составе четвертой группы было принято для того, чтобы достичь большей откровенности со стороны респондентов. Полученные мнения были дополнительно проверены с помощью индивидуальных интервью.

В Армянске было проведено две фокус-группы: ФГ1 - с работниками главного предприятия города («Крымский титан»), обеспечивающего основную занятость населения; ФГ2 - с предпринимателями, активно контактирующими как со своими украинскими, так и российскими партнерами.

В Троицке - самом большом из выбранных городов - было проведено пять фокус-групп: ФГ1 - с пенсионерами, которые здесь, как и в Джанкое, составляют наиболее значимую группу населения; ФГ2 - с рабочими Троицкой ГРЭС (основной работодатель города); ФГЗ - с менеджментом ГРЭС и руководителями среднего звена сохранившихся производств; ФГ4 - с представителями малого бизнеса, ФГ5 - с работниками бюджетной сферы.

В Забайкальске, где состав населения существенно изменился в постсоветские годы, для общения были выбраны местные предприниматели, ориентированные на внешние контакты (ФГ1), и местные служащие, связанные с локальным социумом (ФГ2).

Хотя среди наших респондентов преобладали русские, состав фокус-групп был смешанным и соответствовал этнической структуре населения каждого из городов. При проведении фокус-групп соблюдались все необходимые процедурные требования, включая аудио- и видеозапись, звуковые файлы были затем переведены в текстовую форму для дальнейшего анализа. Высказывания респондентов, приводимые в тексте статьи, даются в кавычках с обозначением места проведения и номером фокус-группы. 


\section{ГРАНИЦА КАК ИСТОЧНИК УГРОЗ И ГАРАНТИЯ БЕЗОПАСНОСТИ: ТРИ ВЗГЛЯДА НА ПРОБЛЕМУ}

\section{АРМЯНСК И ДЖАНКОЙ: СПУТАННЫЕ ОРИЕНТИРЫ}

Согласно опросам общественного мнения, Китай и Казахстан рассматриваются значительной частью российского населения как друзья и союзники России, а Украина как недружественная, враждебная страна ${ }^{10}$. Однако одно дело, когда к таким выводам люди приходят после просмотра телевизионных передач, и другое, когда к ним подводит личный опыт. Как выразился один из наших респондентов в Армянске (ФГ1): «Отношения России и Украины - это бесконечные дебаты. Вот, когда блэкаут устроили, вот это проблема! А сейчас импортозамещение и вода тоже!». Поэтому неудивительно, что в Армянске и Джанкое отношения между двумя странами оценивались как «тяжелые, катастрофические, напряженные, недружественные, агрессивные и враждебные». Одновременно рефреном звучало: «Жалко людей, а просвета нет. И еще надолго» (Джанкой, ФГ4). Респонденты говорили одно и то же: человеческие контакты должны сохраняться вопреки всем обстоятельствам. «Люди хотят дружить, а из-за политиков им этого не удается» (Армянск, ФГ1). «Мы ближе всех находимся к Украине. Поэтому это один из наших больных вопросов - связь с Украиной. У нас там родственников очень много. А нас почему-то в этом ущемляют» (Джанкой, ФГ2). Голоса тех немногих, кто не имел связей в Украине, никогда туда не ездил и не собирался в будущем, звучали в этом хоре диссонансом.

Если оценивать в целом результат проведенных фокус-групп, то одно из наиболее ярких впечатлений - противоречивость коллективных представлений, сильно окрашенных эмоциями. Люди с энтузиазмом рассказывали нам о событиях весны 2014 года, пережитом душевном подъеме и чувстве солидарности и одновременно всей душой желали сгладить последствия сделанного выбора. Они искренне полагали, что смена государственной принадлежности не должна приводить к разрыву теплых отношений между людьми, оставшимися по разные стороны границы. Вряд ли история знает много таких прецедентов. Невозможным это кажется и в случае «нового» российско-украинского пограничья. И дело не только в напряженных отношениях двух государств, официальной пропаганде и стремлении украинских радикалов максимально осложнить жизнь своих бывших сограждан в Крыму. Желание «жить дружно», высказываемое в Джанкое и Армянске, наталкивается на прохладное отношение их родных и близких в Украине.

Хотя опросы общественного мнения систематически показывают, что украинские граждане в целом более доброжелательно настроены к россиянам, чем россияне к украинцам ${ }^{11}$, жители приграничных крымских городов ощущают это иначе. Истории о неприятностях, с которыми люди сталкивались при выезде в

10 «"Друзья” и “враги” России», Левада-Центр, пресс-выпуск, 14 июня 2018 г. http://www. levada.ru/2018/06/14/druzya-i-vragi-rossii-3.

11 «Российско-украинские отношения», Левада-Центр, пресс-выпуск, 23 июня 2017 г. http://www.levada.ru/2017/06/23/rossijsko-ukrainskie-otnosheniya. 
Украину, широко распространены в местном сообществе и имеют характер личного опыта, а не рассказов «соседа». При этом крымчанам кажется, что сами они с пониманием и сочувствием относятся к проблемам украинского населения, встречая в ответ неприязненное и подозрительное отношение. Тем не менее, практически все отмечали, что на смену агрессивным обвинениям в предательстве: «Со мной сестра двоюродная не разговаривает, говорит - вражина» (Джанкой, ФГ1), пришло более спокойное и «более холодное» (Армянск, ФГ1) отношение. Жителям Крыма, уровень жизни которых немного подрос, несмотря на все проблемы и подскочившие цены на продукты, даже кажется, что украинские соседи им завидуют:

Я бываю часто в Украине, очень часто. Я, наверное, больше в Украине, чем здесь сейчас, так сложилось. И если раньше я приезжала и чувствовала враждебность, $[. .$.$] «как ты могла, ты же предательница получается, ты ж предала$ свою Родину», на что я всегда отвечала: «Меня можете называть, как хотите, но у меня есть на этот счет свое мнение», так сейчас это зависть. [...] То есть, у нас немного лучше, вот у нас уровень жизни выше, чем в Украине (Армянск, ФГ2).

0 такого рода зависти говорили многие, однако трудно сказать, в какой мере данное мнение справедливо, а в какой выполняет функцию компенсации морального ущерба, нанесенного людям обвинениями в предательстве со стороны их близких и друзей.

Несмотря на болезненность проблемы российско-украинских отношений, никто из наших респондентов не считал ее первостепенно важной для России. Людям казалось, что это их локальные трудности. Высказанные мнения обнаруживали двойственность чувств, с одной стороны, бессилия отдельного человека, вовлеченного в исторические события, а с другой - восхищение мощью российского государства, наделяемого всеми атрибутами «подлинности» - от мирового влияния до патерналистской защиты населения. 0 величии России говорили много, противопоставляя его упадку государственности в Украине, полагая ее несостоявшейся и несамостоятельной страной.

Подавляющее большинство наших респондентов было удовлетворено новым российским статусом полуострова. Говоря «наша страна» или «наше государство», люди имели в виду Россию, а не Украину. Вместе с тем далеко не все были готовы оплачивать сделанный выбор ценой отказа от привычек, ущемления личного удобства и комфорта. Характерный диалог:

- Стало тесно в Армянске, столько людей на нашу маленькую площадь города. Все наши свободные места просто обитания, тот же залив, все сейчас... заняты. Там солдаты везде. Солдаты, солдаты... На Каркинитский залив - и на тот просто так не поедешь...

- Солдаты - это же защита вашей безопасности!

- Солдаты - согласна. Но почему они не отойдут метров на триста, чуть-чуть подальше. Пляж оставьте нам. [...] Подвиньтесь чуть-чуть! (Армянск, ФГ1). 
Проигрывание с респондентами ситуации с полной открытостью границы и, напротив, ее закрытостью, также показало совмещение противоречащих друг другу мнений. Если кратко обобщить, то получается следующее: ужесточать пограничный режим нельзя, он и так достаточно неудобен и создает множество проблем в частной жизни, но и смягчать тоже нельзя, поскольку соседство с враждебно настроенным государством сулит одни неприятности. Приграничное положение городов заставляет их жителей чувствовать себя жертвами обстоятельств, первыми попадающими под удар, и такой сценарий пугает. Хотя мало кто верит в возможность открытого вооруженного конфликта, в Армянске обсуждают, сколько времени потребуется украинским и российским ракетам, чтобы достичь города, а в Джанкое - возможность потенциальных провокаций и терактов.

Ощущение беззащитности сочетается с уверенностью, что граница обеспечивает спокойствие и безопасность. «Граница - это удивительная вещь. Переступаешь через порог, и чувствуешь в этот момент: уфф, слава Богу, дома. Да, защита, покой. Ты пересекаешь границу - и тебе сразу становится спокойно» (Джанкой, ФГЗ). Развитие этой темы показало, что речь идет о безопасности идентичности, ее защищенности, ощущении вписанности личных координат в культурный контекст нации. Большинство респондентов приписывало российско-украинской границе важное символическое значение рубежа государственно-политических юрисдикций, обеспечивающих поддержание ясно выраженных местных ценностных приоритетов - признания особости Крыма и его тесной связи с историей России.

Однако чувство национальной (гражданской) принадлежности далеко не всегда наполнено гражданским смыслом. Умозрительный диалог между городом и Россией и между городом и Украиной показал, что в первом случае он ведется с государством, а во втором - со страной и людьми. От жителей Украины хотят «прозрения», а от российского государства - социального обеспечения. При этом модель отношений между локальным сообществом и государством многим видится как политический торг: лояльность в обмен на блага. «Армянск говорит: “Россия, ты взяла на себя такую ответственность, взяла меня [...] к себе, в пределы своего государства? Значит, улучши наше положение, чтобы мы не пожалели, что стали частью такой большой страны"» (Армянск, ФГ1). К подобным высказываниям можно относиться по-разному, но не стоит видеть в этом вызов или угрозу. Ориентация на узкий круг локальных взаимоотношений, пассивная подданническая позиция, требования патерналистской защиты и гражданская ответственность, как правило, присутствуют в политической культуре любых обществ, хоть и в разных пропорциях (Almond and Verba [1963] 1989). Рост значения последней в этом симбиозе требует не только развития гражданской культуры, дефицитной как в России, так и в Украине, но и повышения ответственности управленческих и политических элит, их вовлеченности в жизнь и проблемы приграничных сообществ.

\section{ТРОИЦК: БАНАЛЬНОСТЬ ПРИГРАНИЧНОСТИ}

Ситуация Троицка принципиально иная. Казахстан рассматривается как дружественная страна, соседство с которой не представляет опасности. Говоря о границе, 
наши респонденты сопровождали свой рассказ такими словами, как «гости», «друзья», «бешбармак», «рыбалка», «поездка на кладбище», «родственники», «колхоз».

В 2004 году к нам приехали из Москвы, инспекторская проверка на границу Казахстана. Эти ребята молодые, офицеры, они представили себе, что это контрольно-следовая полоса, вышки, пулеметы, пограничники с псами стоят с той стороны, с этой стороны. А тут степь и маленькая речушка. [...] Они говорят: «Где тут у вас спрятаться, где посмотреть в бинокль-то?». А что тут смотреть-то, вон казахи, сейчас поедем к ним, водки попьем, приедут к нам, они у нас попьют. Шашлык сделаем, бешбармак (Троицк, ФГ4).

Хотя граница создает неудобства, затрудняя привычное общение, деятельность малого бизнеса, функционирование рынка труда и доступ к традиционным местам отдыха, большинство респондентов отмечало ее слабое влияние на повседневную жизнь. Говоря о близости границы к городу, люди обсуждали расстояние до ближайшего пограничного пункта пропуска и время, необходимое, чтобы туда доехать. Граница, проходящая совсем рядом с Троицком, воспринималась не как линейный, а как сравнительно удаленный точечный объект. В отличие от Крыма, здесь никому не приходило в голову, что это физический рубеж, разделяющий две страны. Напротив, люди помнили о неоднократных пространственных блужданиях границы, считая ее произвольно проведенной в советские годы. Обретение этой границей государственного статуса не сделало местных жителей чувствительными к вопросам пограничной безопасности. Представления о сопряженных с ней опасностях или выгодах настолько стерты, что люди начинают думать, какие же бонусы можно извлечь из приграничного положения. «Город, если он пограничный, может, ему какой-то статус присвоить? Все-таки он возле границы, значит, может, ему усилить... охрану» (Троицк, ФГ2).

Особость места, подчеркнутая статусом и усиленной охранной, в их глазах выглядела дополнительным ресурсом развития и не сопоставлялась с последствиями, к которым может привести реализация подобных предложений. Характерно, что и сами эти выгоды в Троицке воспринимались умозрительно и связывались не с возможностями приграничной ренты, извлекаемой местным населением из ситуации открытости границы (челночная торговля, мелкооптовая контрабанда, приграничное сотрудничество, более высокое разнообразие услуг, и прочее), а с деятельностью государства. На дефицит государственного внимания жаловались все наши респонденты, характеризуя Троицк как «забытый» и «заброшенный».

Слабая чувствительность жителей Троицка к пограничной тематике проявились и при обсуждении вопроса о защите границы и ее защитниках. Во-первых, сама постановка вопроса вызвала у людей недоумение: «0т кого защищаться? От друзей?» (Троицк, ФГ1), а во-вторых, всем было очевидно, что эта функция лежит на государстве и погранвойсках. Хотя в группе пенсионеров звучали слова о Троицке как «форпосте Родины», все это была дань риторике, усвоенной с советского времени. Представление о жителях приграничных городов как носителях идеи защитников рубежей страны оценивалось как «московская иллюзия обмана» 
(Троицк, ФГ4). Модель обеспечения безопасности через интеграцию и поддержку контактов между жителями соседних российских и казахстанских регионов также не рассматривалась как фактор снижения пограничных угроз, поскольку, «если дело дойдет до введения войск, то войскам-то по барабану - дружим мы - не дружим, общаемся - не общаемся» (Троицк, ФГЗ).

В этой реакции слышится эхо событий на российско-украинской границе, где еще совсем недавно местные жители также не предполагали возможность конфликта и были уверены в тесном сотрудничестве двух стран, несмотря на разногласия политических элит. Однако, проводя параллели, наши респонденты более всего опасались не противостояния России и Казахстана, а вмешательства третьих сил. «Украина, видишь, откололась, уже американцы там. Оно нам надо? В огороде у нас!» (Троицк, ФГ2). При этом сама по себе ситуация размежевания двух государств и установления ими контроля над своей территорией воспринималась жителями Троицка как норма. Граница характеризовалась как непременный атрибут государства, сравнивалась с порогом или дверью дома, которые отделяют от внешнего мира. В то же время людям очень хотелось, чтобы этот мир не содержал в себе никаких сюрпризов, был понятен и неизменен. Перемены в соседней стране воспринимались с большой настороженностью: «... Наш любимый Назарбаев... что он учудил? На латиницу переходят к 2025 году? Переходят! Зачем? Непонятно» (Троицк, ФГ5).

Основные тревоги жителей приграничного Троицка были связаны не столько с опасностью жизни на границе, сколько с ее влиянием на периферизацию города. Людям казалось, что именно фактор пограничности был определяющим при переводе головных финансовых и налоговых организаций из их города (ранее несомненного территориального центра) в соседний Южноуральск, который значительно уступает Троицку по всем характеристикам, но расположен дальше от границы и ближе к региональной столице - Челябинску. Этим же объяснялось и строительство там крупнейшего логистического центра, рассчитанного на трансграничные потоки товаров.

Ощущается и утрата культурного влияния Троицка на сопредельные территории Казахстана: сократился поток казахстанских студентов в местные вузы, уменьшается влияние города как центра религиозной жизни. «Раньше наши троицкие мечети поддерживали, как ни крути, казахи. Десять лет назад они у себя в Карабалыке - это 46 километров отсюда - построили огромную мечеть, чуть ли не ЛяляТюльпан в Башкирии или Соборная мечеть в Москве. [...] И все казахи поехали туда» (Троицк, ФГ4).

По мнению респондентов, государство - единственная сила, которая может остановить процесс периферизации, но оно вместо этого уходит из всех сфер местной жизни, оставляя за собой лишь технические функции на границе и сферу символической политики. Если Казахстан в приграничье подчеркивает государственное значение ислама, то Россия - православия. «Сколько у нас церквей в Троицке! Вы проезжали, наверное, видели. [...] Для чего вообще, смысл? Столько церквей, у нас народу столько нет» (Троицк, ФГ4). Раздражение, с которым говорилось о церковном «ренессансе», дополняет общую картину недовольства мест- 
ного населения, вызванного сравнением неутешительных реалий сегодняшнего дня и благополучных - вчерашнего.

Всего двадцатилетие назад достигнутый уровень экономического развития города не оставлял сомнений - Троицк переживет все потрясения. Даже на случай войны у него есть ресурсы самообеспечения: и хлеб, и масло, и тепло с электричеством, и свои машиностроительные заводы, и замечательные кадры. Сегодня эта уверенность растаяла, ей на смену пришли сильнейшая фрустрация и уныние. 0днако даже на беглый взгляд внешнего наблюдателя, было заметно, что эта обездоленность имеет относительный характер: население Троицка не столько живет, сколько чувствует себя плохо. Феномен релятивной депривации был детально проанализирован Юрием Левадой еще в 1990-х годах (Левада 1999), он же указал на связанный с этим риск компенсации внутреннего недовольства за счет «раздувания» роли внешних факторов. И хотя близость границы не вызывает беспокойства у жителей Троицка, они видят прямую связь между своими личными проблемами и позицией государства в управлении ситуацией на границе, частью которой они себя считают. Это тот внешний фактор, который разрушает «состояние защищенности» и вызывает ощущение «объективной» угрозы.

\section{ЗАБАЙКАЛЬСК: В ТЕНИ КИТАЯ}

Отношение к границе у жителей Забайкальска принципиально иное, чем в городах Крыма или Троицке: она рассматривается как источник доходов и основное место приложения труда. По мнению наших респондентов, в челночную торговлю вовлечено большинство жителей поселка и окрестных сел: «Самая-самая здесь, самая главная, самая востребованная профессия связана с Китаем... - это перевозчик что ли по-русски, называется... “кэмел"» (Забайкальск, ФГ2). Благодаря близости к границе «у людей более-менее деньги есть» (Забайкальск, ФГ1). Этот фактор является более значимой гарантией благосостояния населения, чем наличие крупных производств, как, например, в соседнем «городе атомщиков» Краснокаменске. Несмотря на риски, сопряженные с трансграничным бизнесом, балансирующим на грани закона, в него вовлечены все слои местного населения. Это накладывает определенный отпечаток на отношение к пограничному режиму. Гипотетическое предложение о закрытии границы было встречено респондентами негативно: «Кусок хлеба отнимете» (Забайкальск, ФГ1), но и открытие границы не вызывало энтузиазма. С одной стороны, было бы неплохо пересекать границу «как в Евросоюзе», чтобы «можно было бы походить туда пешком [...] бесплатно» (Забайкальск, ФГ2), но с другой - открытие границы «лишит пенсионеров заработка» (Забайкальск, ФГ1).

Рассуждая об открытости границы, наши респонденты не говорили о «китайской угрозе». Этот сюжет возник в связи с вопросами о безопасности и особенностях защиты границы. Как и в других приграничных городах, в Забайкальске особо выделяли символические функции границы, недвусмысленно разделяющей не только государства, но и культурные миры. Однако в возможность каких-либо вооруженных конфликтов или агрессивных действий на российско-китайской границе никто из респондентов не верил. Эти страхи оста- 
лись в прошлом, когда в Забайкальске каждый знал, где находится бомбоубежище и как следует себя вести в случае нападения. Сегодня больше обсуждают риски контрабанды и теневой торговли. К границе привыкли, и люди полагают, что главным инструментом ее защиты является стабильность политических отношений, «просто оттуда никто не рвется, и отсюда тоже никто» (Забайкальск, ФГ2). В то, что граница может их защитить, люди не верят. По их мнению, охрану границы обеспечивают не столько военные, сколько факт наличия приграничных городов и живущего здесь мирного населения, ассоциирующего себя с Россией.

Вообще нам надо платить за то, что мы тут живем... Вот якутам же платят за то, что они там алмазы берегут. И нам надо деньги за то, что мы тут границы бережем. То, что живем просто здесь, занимаем территорию. Хоть какой-то населенный пункт... (Забайкальск, ФГ1).

Хотя в Забайкальске, как во многих других пограничных городах, люди ощущают себя «забытыми» страной и «брошенными» государством, далеко не все чувствуют себя жертвами обстоятельств. Местный социум переживает глубокую трансформацию: на смену обветшавшему гарнизонному стилю советской жизни, главной чертой которого была закрытость, приходят новые стандарты потребления, привычки, круг общения и опыт взаимодействия с китайскими соседями. Несмотря на то, что сравнение себя с Маньчжурией порождает фрустрацию, далеко не всегда испытываемая обида (или даже зависть) трансформируется в депрессивное состояние или агрессию по отношению к «другим». В отличие от жителей Троицка, где господствует тотальное уныние, в Забайкальске мы столкнулись с полным спектром настроений - от упадническо-пессимистических до уверенно-оптимистических. Многие верят в свои перспективы и связывают их с близостью границы, предпочитают жить в Забайкальске, «где даже воздух не такой, как в Китае» (интервью с таксистом, м., 42 года), но иметь возможность постоянно ездить туда, выстраивая свой бизнес. 0 местных жителях нельзя сказать, что они дезориентированы, но им очень хотелось бы выйти из «тени» Китая, ощутить большую сбалансированность качества жизни по разные стороны границы и меньшую зависимость своего благополучия от соседней страны. Выход из этой ситуации они видят в изменении подхода государства к пограничным территориям.

\section{СРЕДОВОЙ КОНТЕКСТ ЖИЗНИ КАК ФАКТОР ВОСПРИЯТИЯ ГРАНИЦЫ \\ ОТНОШЕНИЯ «МЫ» И «ДРУГИЕ»}

Позитивность этнической самоидентификации и отсутствие негативного отношения к другим народам, по мнению этнологов, являются залогом успешного выстраивания межгрупповых взаимодействий (Магун, Дробижева и Кузнецов 2006). Но как это правило работает на пограничных территориях? Их история нередко хранит память о вражде и конфликтах, а актуализация трагических со- 
бытий прошлого является одним из механизмов легитимации действий современных политиков, включая секьюритизацию границ. В нашем случае в фокусе внимания были «русские», которые являются не только наиболее многочисленной, но и наиболее статусной группой населения выбранных приграничных городов. Набор контактных этнических групп определяли сами респонденты, но в их составе обязательно присутствовали этносы, имеющие государственность с другой стороны границы: а) украинцы, в случае городов Крыма; б) казахи и китайцы - в Троицке; в) китайцы - в Забайкальске. Обобщение материалов всех фокус-групп позволило сделать следующие выводы.

Во-первых, этническая проблематика на выбранных участках российского пограничья является слабо актуализированной. Для русских, казахов и украинцев, проживающих на приграничных территориях, был характерен баланс позитивных и негативных оценок как в отношении «себя», так и «других». Позитивные предикаты были практически идентичны: русские, украинцы и казахи характеризовались как душевные, простые, гостеприимные, миролюбивые, умные, и пр. Негативные - имели больше отличий: так, украинцев характеризовали как жадных и хитрых, чего не думали о себе, казахов - как отсталых и властолюбивых, а русских - как непатриотичных. Однако в целом наши респонденты не видели особой разницы между русскими и украинцами, русскими и казахами. Поскольку этнический состав фокус-групп не был однородным, а респонденты имели возможность выразить свое отношение к представителям других народов скрыто, то такой результат свидетельствует об отсутствии взаимной предвзятости. Образ «китайца» строился иначе, но и в нем сохранялся баланс позитивных и негативных качеств. В Троицке он был обрисован в очень общих чертах (жители Троицка контактировали с китайцами эпизодически и преимущественно на своей территории), а в Забайкальске - более детально. Интенсивность контактов местного населения на российско-китайской границе способствовала тому, что к китайцам «уже привыкли, как к своим» (Забайкальск, ФГ2). Основные позитивные характеристики китайцев в обоих городах сводились к их энергии, трудолюбию и миролюбивости, а отрицательные - к жестокости, скрытности и высокомерию. Если кратко подвести итог, то из теста следует, что взаимное узнавание, опыт совместной жизни и частота межкультурных контактов играют огромную роль в межгрупповой адаптации, но не позволяют до конца преодолеть этнокультурные предубеждения. Сбои взаимодействий и личный неудачный опыт рассматриваются людьми как подтверждение устойчивых, часто предвзятых, стереотипов. Любые разногласия на межгосударственном уровне аукаются в пограничье оживлением подспудных страхов и неприязни. Однако эти страхи именно подспудные, так как стерты в повседневной жизни людей, не воспринимающих границу как опасность, а своих соседей как врагов.

Во-вторых, повторение в разных городах одних и тех же предикатов в отношении «русских» и контактирующих с ними этносов (Гудков, Дубин и Левинсон 2009; Свинчукова 2011; Снежкова 2013) свидетельствует о неслучайности элементов выявленных образов. Особенно удивительным выглядит сходство современных характеристик китайцев с теми, что бытовали в российско-китайском по- 
граничье более века назад (Дятлов 2000). Устойчивость представлений о «себе» и соседях, проявляющаяся как на коротких, так и длинных временных отрезках, говорит о неустранимости этнических стереотипов и сомнительной возможности произвольного конструирования и изменения образа соседа, а также о меньшей подверженности приграничных социумов влиянию текущей политической конъюнктуры, чем общества в целом.

В-третьих, практически полное совпадение самоопределений русских, несмотря на значительную удаленность городов исследования друг от друга и отсутствие связей между ними, однозначно свидетельствует о принадлежности их населения единой культурной общности. Это подтверждает тезис, высказанный в Забайкальске: наличие приграничного населения, культурная определенность которого не вызывает сомнений, является важным условием защищенности границ.

Не менее важно, что приграничный социум имеет инклюзивный характер. Наши респонденты на всех фокус-группах придавали меньшее значение этнической принадлежности и большее - индивидуальному выбору человека и соблюдению принятых социальных норм поведения. Данная особенность проявилась не только на российско-украинской или российско-казахстанской границе, где люди не видели большой разницы между собой и соседями, но и на российско-китайской. Это свидетельствует о высокой адаптивности приграничных социумов к складывающейся ситуации, способности «овладевать» ею. Свободная ориентация людей в нормах и правилах поведения, принятых в соседней стране, позволяет им оставаться «самими собой» и быть «как все» с какой бы стороны границы они ни находились. Этот феномен позволяет говорить о наличии элементов трансграничных сообществ на разных участках российской границы независимо от имеющихся родственных связей.

\section{ПОГРАНИЧНЫЙ ГОРОД КАК МЕСТО ЖИЗНИ}

Рассуждая о пограничных городах невозможно отвлечься от представления об их особой географической позиции и двойственности ее восприятия: то ли фасад страны, то ли задворки. Если к крупным городам применяется скорее первое определение, то к малым и средним - второе. Очевидным проявлением их периферийности является отток населения и его активное замещение. В прежних геополитических реалиях эти процессы рассматривались как норма, более того, даже проводилась политика отселения от границ и создания здесь буфера природных заповедников, но сегодня обезлюдение пограничья воспринимается как угроза национальной безопасности. Проблема не в военной уязвимости границ, местные жители не в состоянии ее защитить и не видят себя в роли «щита отечества», а в новых информационных и миграционных вызовах. И, если личное благополучие жителей приграничья, располагаемые возможности и выбираемые жизненные ориентиры напрямую зависят от проводимой пограничной политики, то и государство зависит от социального самочувствия приграничного населения, его настроений, интересов и разделяемых идентичностей (Хвощев 2001). 
Было бы неверно сводить такую взаимозависимость только к социально-экономическим характеристикам и уровню жизни населения. При всей важности этих параметров, безопасность идентичности и качество жизни волнуют людей не меньше, чем размер зарплат, сжимающийся рынок труда и растущие цены. Во всех проведенных фокус-группах респонденты уверяли нас, что хотели бы ездить «туда», где есть свои преимущества, но жить «здесь», несмотря на тяготы местной жизни. Основной лейтмотив обсуждаемых городских проблем при всей их приземленности сводился к подчеркиванию «дефицита радости» и отсутствию возможностей самореализации. Например, в Джанкое - степном городе, высушенном солнцем, - нашим респондентам не хватало яркости и «чего-то солнечного» (Джанкой, ФГЗ), в Армянске - перспектив. Жителям Троицка казалось, что их город все меньше отличается от деревни, а Забайкальска - что государство должно проводить такие же массированные интервенции в городское развитие, как в соседней Маньчжурии, превращая приграничный поселок в туристический аттракцион. Чем острее жители пограничных городов ощущали дефицит радости, тем сильнее были выражены пессимистические оценки места их жизни (табл. 1).

Таблица 1. Приграничные города глазами своих жителей (\% от числа высказываний)*

\begin{tabular}{|l|l|l|l|l|}
\hline Группы определений & Джанкой & Армянск & Троицк & 3абайкальск \\
\hline $\begin{array}{l}\text { Маленький/небольшой, } \\
\text { спокойный, тихий, мирный, } \\
\text { обычный, поселок }\end{array}$ & 17 & 32 & 13 & 5 \\
\hline $\begin{array}{l}\text { Родной, любимый, светлый, } \\
\text { солнечный, чистый, добрый, } \\
\text { гстеприимный, красивый }\end{array}$ & 27 & 30 & 36 & 2 \\
\hline $\begin{array}{l}\text { Старинный, исторический, } \\
\text { культурный }\end{array}$ & - & - & 9 & - \\
\hline $\begin{array}{l}\text { Брошенный, разрушающийся, } \\
\text { неустроенный, грязный, } \\
\text { неказистый, бедный, } \\
\text { проблемный }\end{array}$ & 25 & 22 & 20 & 46 \\
\hline $\begin{array}{l}\text { Серый, провинциальный, } \\
\text { сонный, скучный, неуютный, } \\
\text { неразвиващийся, пассивный, } \\
\text { печальный, терпеливый, } \\
\text { сельский, большая деревня }\end{array}$ & 13,5 & 3 & 4 & 27 \\
\hline $\begin{array}{l}\text { Меняющийся, развивающийся, } \\
\text { благоустраивающийся }\end{array}$ & 8 & 5 & 2 & 5 \\
\hline $\begin{array}{l}\text { Пограничный, важный, «наш» } \\
\text { русский город }\end{array}$ & 3 & 5 & 5,5 & 5 \\
\hline $\begin{array}{l}\text { Многонациональный, } \\
\text { интернациональный }\end{array}$ & 1 & - & 5 & 2,5 \\
\hline $\begin{array}{l}\text { Хамоватый, «гангстерский», } \\
\text { хулиганский }\end{array}$ & 1 & - & 1 & - \\
\hline $\begin{array}{l}\text { Веселый, спортивный, } \\
\text { «отдыхательный», зеленый, } \\
\text { экологичный }\end{array}$ & 4 & 4 & 7 \\
\hline
\end{tabular}

* Собранный массив данных зависел от количества проведенных в городах фокус-групп, в Армянске было получено 38 эпитетов-определений города, в Забайкальске - 41, Джанкое 113 и Троицке - 95. 
Немаловажную роль играло и сравнение себя с «другими». Однако, проводя параллели, наши респонденты не выбирали населенные пункты сходного размера и статуса и даже не видели в этом особого смысла. Они обращались к заведомо контрастным примерам, подчеркивающим их бедственное положение и/или периферийность малого города. В качестве референтных образцов выступали курорты южного берега Крыма (Ялта, Гурзуф, Алупка), крупные региональные центры (Челябинск, Кустанай, Чита, Симферополь, Маньчжурия) и даже Москва. Подобное сравнение выполняло сразу несколько функций: оно объясняло, чем малый город лучше большого и почему не стоит покидать «насиженное гнездо», легитимировало запрос на поддержку со стороны государства и допустимость нарушения установленных государством правил. Невольно вспомнишь «человека лукавого», двоемыслие которого связано с приспособлением к конкурирующим социально-нормативным представлениям (Левада 2000).

Различия географического, исторического, социального и экономического контекста жизни приграничных городов накладывали отпечаток на их восприятие (табл. 1). Эта связь легко выявляется и не вызывает трудностей в интерпретации. Так, малое число эпитетов, отражающих «любовь» к Забайкальску, объясняется большим количеством приезжих как в составе населения поселка, так и фокусгрупп, а восприятие его как «неустроенного» - близостью к сверкающей огнями Маньчжурии. Но те же факты делают Забайкальск самым «веселым» среди выбранных городов. В Армянске ощущение провинциальности города замещается представлением об его «обычности», и, действительно, город соответствует всем градостроительным стандартам советской эпохи, чего не скажешь о соседнем Джанкое. В Троицке те же эмоции компенсируются глубоко укорененным представлением о «необычности» города, его исторической значимости и центральности для обширного региона.

Если различия в траекториях развития приграничных городов диверсифицируют их восприятие, то субъективные ощущения людей, напротив, делают их очень похожими. Структурная близость нарисованной нашими респондентами картины городской жизни дает еще одно подтверждение тезиса о значительном культурном единстве российского пограничья. Фактически мы сталкиваемся с тем, что очень разрозненное, дробное, вытянутое на тысячи километров, визуально различное и слабо связанное физическое пространство сохраняет свое единство как пространство власти, и прежде всего власти социальной и культурной, субъектом которой является население.

Несмотря на близость границы и осознание людьми этого факта, приграничные города воспринимаются в первую очередь как «место жизни» и только затем как пространство национального суверенитета - пограничная зона. Граница перестала быть для людей чем-то экстраординарным, создаваемые ею проблемы рассматриваются как второстепенные по сравнению со стагнацией городского развития. В то же время ощущение близости границы делает все эмоции более яркими и контрастными, усиливает непоследовательность поведенческих реакций, обостряет чувство одиночества, брошенности, неуверенности в себе и своем будущем, страх оказаться «жертвой» обстоятельств и пассивное сопротивление 
их непреодолимой силе, которое выливается в вербальную агрессию против реальных или мнимых виновников ситуации. Связь представлений о «своем» городе как неотделимом от границы, а о границе как зоне исключительной ответственности центральной власти и ее институтов приводит к делегированию ответственности за обустройство местной жизни государству. Раз оно обязано заботиться о безопасности своих границ, то должно обеспечить и благополучие приграничных жителей, они - первые в очереди за государственной опекой. А на деле получается, что вместо «счастливого» билета им выпал «несчастливый».

\section{НЕСЧАСТЛИВОЕ ПОГРАНИЧЬЕ ВЕЛИКОЙ СТРАНЫ}

Воображаемый диалог между малым пограничным городом и большой страной, который разыгрывался в фокус-группах, каждый раз сводился к одному сценарию с незначительными вариациями. Город просил о «золотом дожде», а Россия, взглянув в лупу, отвечала, что «денег нет, но вы держитесь». Был и другой вариант: «Не надейтесь на нас, сами давайте, работайте». В этом контексте можно было бы ожидать, что пессимистический взгляд на собственную жизнь будет транслироваться и на отношение к стране. Однако это оказалось не так. Определения, которые адресовались России, были разнообразны, чрезвычайно позитивно окрашены, отражали гордость и боль за родину.

Среди всего массива эпитетов на долю дескриптивных описаний («большая страна, обладающая природными богатствами») приходилось порядка 15\% высказываний, а еще 8\% характеризовали Россию как «многонациональную, дружную и федеративную». Самый большой блок (23\%) составляли такие эпитеты, как «великая, могучая, сильная, ядерная, мощная и хорошо вооруженная держава», подспудно содержавшие эмоции гордости и уважения. Затем следовали открытые выражения любви (16\%): «родная, любимая, наша, хорошая, лучшая страна в мире, гордимся Россией». Еще 8\% пришлось на чувственное выражение восхищения - «волнующая, классная, красивая, жизнерадостная, яркая, необычная». Отдали наши респонденты дань и «мудрости» страны, назвав ее «справедливой, законной, доброй, терпеливой, христианской, благотворительной и щедрой» (11\%). В этом списке похвал присутствовали и эмоции боли, переживаний за испытываемые трудности (6\%): «многострадальная, кровоточащая, погибающая, больная, напряженная». Еще 4\% эпитетов характеризовали Россию как страну «слабую, растратившую силы в борьбе с собой, раздвоенную на богатую столицу и живущую плохо провинцию»; 3\% - напротив, считали Россию «развивающейся». В этом облаке определений (14 фокус-групп позволило собрать 156 эпитетов-характеристик России) присутствовало и небольшое число разрозненных одиночных высказываний: «спортивная, студенческая, соседняя с Китаем, нормальная, сложная, разная» и пр.

Никто из наших респондентов не характеризовал Россию как авторитарную, имперскую, агрессивную, коррумпированную, бюрократическую, олигархическую, деградирующую, запущенную, вымирающую и т. д.

Вряд ли контраст между идеализированным образом России и негативным своего города можно объяснить отсутствием опыта путешествий, влиянием теле- 
визионной пропаганды или малым размером населенных пунктов, жители которых, как правило, не склонны оппонировать власти. Если мир приграничных городов северного Крыма действительно представляется довольно замкнутым и ограниченным ближайшим окружением, то этого не скажешь о Троицке и Забайкальске. В «багаже» их жителей поездки по разным регионам страны и за рубеж. Рассуждения людей о российских проблемах демонстрировали их осведомленность и не сводились к общеизвестной формуле о дураках и дорогах. Назывались такие беды страны, как бедность, социальная несправедливость, произвол чиновников, низкое качество управления, коррупция, неустроенность жизни, миграционный отток населения, международное давление и санкции, безработица, территориальное неравенство; вспоминали о терроризме и разобщенности населения.

Не получается объяснить выявленный диссонанс общественных представлений трансформацией нигилизма в показной патриотизм, тягой к государственному патернализму и отсутствием у малых городов достаточных ресурсов развития. На фокус-группах звучала столь резкая критика властей всех уровней и проводимой ими политики, что о верноподданничестве говорить не приходится.

Неубедительной выглядит и версия об оторванности жителей пограничья от «материка России», предстающего как далекая идеальная страна молочных рек и кисельных берегов. Близость границы не оставляет сомнений - Россия именно здесь. Видимо, объяснение следует искать в другой плоскости. Похоже, что совмещение конфликтующих представлений в сознании людей связано с разделением базовых (неизменных) и меняющихся реалий. При этом «все хорошее» соотносится с изначальным и постоянным, а «все плохое» - с временным и преходящим. В этом контексте Россия воспринимается как фундамент жизни и основа основ, а ситуация в «своем» городе - как подлежащая изменению. Вполне возможно, что непоследовательность реакций приграничного населения (острая неудовлетворенность своей жизнью и столь же яркое выражение гордости за страну) связана с обостренным ощущением размывания «незыблемого» ценностного фундамента в результате действий местных руководителей-временщиков. Для многих из наших респондентов ответственность за «плохое» и «хорошее» была разделена и персонализирована. В этом контексте несовпадение образа города и образа страны можно интерпретировать как отражение ощущаемой людьми угрозы безопасности личности и унижения человеческого достоинства, стремления заслониться от нее. Однако это только предположение, которое нуждается в дальнейшей проверке.

\section{ЗАКЛЮЧЕНИЕ}

Стратегия национальной безопасности России рассматривает безопасность как объективное состояние защищенности от угроз, к которому следует стремиться. Движению в этом направлении, по мнению ее авторов, способствует реалистичная политика, которая исходит из представлений о национальном суверенитете и главенстве национальных интересов. Теория секьюритизации, напротив, предлагает рассматривать безопасность как дискурсивную практику, направленную на изме- 
нение структуры приоритетов общества и контроль процессов, происходящих в разных сферах социальной жизни. Реализация этой цели предполагает постулирование экзистенциальных угроз, значимых для конкретной аудитории, и предложение мер (часто чрезвычайных) для снижения или ликвидации рисков. Другими словами, безопасность - это не «объективное состояние защищенности», а политическая метафора, за которой скрывается борьба различных субъектов власти за перераспределение ресурсов влияния и мобилизацию поддержки. Несмотря на ортогональность этих подходов к пониманию сути политики безопасности, только их сочетание позволяет дать адекватное описание ситуации в малых населенных пунктах российского пограничья.

Восприятие границы как культурного водораздела и маркера идентичности, а государства как союзника, гаранта социального порядка и защитника от внешних и внутренних угроз, создает общественный консенсус в отношении мер безопасности и нормализует течение повседневной жизни. Это отчетливо прослеживается в городах Крыма. Жители Армянска и Джанкоя, рассуждая о внешних угрозах и своей безопасности, приводят аргументы, сходные по смыслу с официальной позицией российских властей, и позитивно оценивают процесс секьюритизации границы. Такое совпадение позиций создает ситуацию, которую можно определить как «объективное состояние защищенности». В остальных городах исследования, где отсутствует фактор межгосударственного конфликта, тот же тренд проявляется иначе. Здесь представление о безопасности связывается с желанием снизить уровень неопределенности будущего благодаря созданию малого приграничного мирка, закрытого как для внутренних неурядиц, так и стихийных процессов, начавшихся за рубежом. Жизнь в этом гипотетическом оазисе благополучия, по мнению части местных жителей, должна быть защищена особым статусом и режимом. Представления о надежности его границ, а не только государственной границы, являются гарантией локальной стабильности.

Тем не менее, далеко не всегда удается достичь подобного консенсуса. Как показало проведенное исследование, гораздо чаще в пограничье наблюдается несовпадение интересов государства и местных жителей. Логика обеспечения безопасности национального суверенитета, требующая множества ограничений для фильтрации возможных угроз, вступает в противоречие с логикой обыденного течения местной жизни, предполагающей открытость и отсутствие барьеров для соседских взаимодействий. Особенно наглядно это проявляется в отторжении пограничным населением дискурса враждебности, который в рамках политики секьюритизации границ систематически воспроизводится на уровне государства и требует мобилизации его военно-полицейских функций. Однако с точки зрения местного населения «враги» находятся где-то далеко, а не с другой стороны границы, разумнее не обороняться от них, а решать насущные социальные задачи. Пограничные структуры государства, в необходимости которых никто не сомневается, должны защищать от угроз иного рода: как надежный работодатель они помогают достичь ощущения материальной и социальной защищенности, а как институты регулирования пограничного режима - упорядочить трансграничные взаимодействия и обеспечить безопасность через контакты и кооперацию. Этот 
вывод справедлив не только для ситуации мирных и открытых границ, но и для случаев соседства конфликтующих государств, наличия существенных различий в представлениях и образе жизни населения, негативного исторического опыта и сохраняющейся этнической предвзятости.

Второе противоречие связано с политикой «национальной консолидации», проводимой государством, имеющей дискурсивную природу и, как правило, направленной на устранение внутристрановых различий. В этом контексте жители пограничья априори считаются подверженными риску нелояльности в силу сложности и изменчивости их идентичности. Свою роль играет и искусственная природа границ, нередко разделяющих единые в культурном отношении территориальные общности. Было бы наивно считать данную точку зрения безосновательной. В мире постоянно растет количество неконтролируемых центральными властями территорий, обладающих суверенитетом де-факто (Попов 2012), многие из них возникли по периметру материнских государств. Однако подобная подозрительность действует разрушительно на местный социум. Для населения приграничных городов, как показывает проведенный анализ, характерно сочетание острого переживания любви к Родине с не менее острым ощущением своей ненужности стране, заброшенности и неустроенности. Уныние, фрустрация и нигилизм усиливают сомнения в существовании национальной общности и наличии объединяющих ценностей. Навязываемая политика национальной консолидации воспринимается как лицемерие и становится контрпродуктивной. Локальное сообщество теряет смысл своего существования, на место веры в жизнеспособность социума (как малого, так и большого) заступает чувство обреченности. Разложение социальной жизни пограничья ослабляет территориальную власть государства в его наиболее чувствительной зоне, лишая его опоры на социальные институты.

Третье существенное противоречие связано с пониманием безопасности как рутинной повседневной работы государства, направленной на реализацию защитных функций. Специализация на безопасности предполагает разделение технической и социальной функций управления границами, выведение связанных с ними вопросов из сферы публичной политики. Это приводит к максимизации значения разного рода технических средств и минимизации участия неспециалистов в принятии решений. Закрытый мир «знатоков своего дела» противопоставляется открытому миру наивных профанов. При таком подходе жители приграничных городов с их требованиями и недовольством оказываются «помехой» для профессионалов. Однако, на взгляд населения, это приводит к недооценке фактора наличия в пограничье обычных поселков, которые, в отличие от пограничных гарнизонов и пунктов пропуска, формируют его мирный ландшафт. Культурная определенность этих поселений недвусмысленно свидетельствует о национальной принадлежности территории, а их социальное здоровье и экономическое благополучие работают на укрепление пространственного каркаса страны, «защищая» ее целостность. Их упадок и обезлюдение, напротив, говорят об отступлении государства от своих рубежей. В логике местных жителей технократическая модель управления границами, предполагающая разделение ответственности между институтами государства, муниципальными образованиями и обществом, сама по 
себе является экзистенциальным вызовом. Вычленение угроз государственной безопасности из общего букета пограничных проблем с предложением местным сообществам, имеющим крайне слабую материальную базу, делать ставку на собственные источники развития, воспринимается как крайний цинизм. Результат такого «разделения» ответственности - деградация приграничных поселений, миграционный отток их жителей и символическое отступление государства из пограничья, несмотря на наличие знаков его технического присутствия.

Предпринятый анализ еще раз подводит к неоднократно высказанной мысли о взаимозависимости государства и населения. Как государство для утверждения своих территориальных прав нуждается не только в демонстрации силы, но и в легитимности, подтверждаемой населением, так и жители пограничья, чтобы ощущать себя частью страны, нуждаются в повышенном внимании со стороны государства. Поэтому вопросы безопасности не стоит рассматривать только как дискурсивную практику, широко используемую властью для продвижения своих интересов и изменения расстановки социально-политических приоритетов в обществе. Подобное конструирование ограничено процессами, происходящими на низовом уровне, в том числе и в малых приграничных городах, сколь бы второстепенными субъектами трансграничных взаимодействий они ни казались.

\section{СПИСОК ЛИТЕРАТУРЫ}

Бельский, Александр. 2009. «Административно-территориальное устройство Крыма: 200 лет истории». Культура народов Причерноморья 155:73-77.

Бийе, Фрэнк. 2014. «Современность в пространственном измерении: открытые рынки, герметичность и вертикальность в двух приграничных городах России и Китая». Экономическая социология 15(2):76-95.

Богатуров, Алексей, ред. 2010. Современная мировая политика. Прикладной анализ. М.: Аспект Пресс.

Бредникова, Ольга. 2008. «Приграничье как социальный феномен (направления социологической концептуцализации)». Вестник Санкт-Петербургского университета. Сер. 12. Социология 4:492-497.

Бредникова, Ольга и Виктор Воронков, ред. 1999. Кочующие гранищы. Сборник статей по материалам международного семинара (Нарва, 12-16 ноября 1998). СПб.: ЦнСИ.

Вендина, Ольга и Владимир Колосов. 2007. «Партнерство в обход барьеров». Россия в глобальной политике 1. https://globalaffairs.ru/number/n_8147.

Герасименко, Татьяна. 2016. «Трансграничные регионы на постсоветском пространстве: специфика, проблемы, перспективы». С. 44-54 в Российское пограничье: социально-политические и инфраструктурные проблемы: Сборник статей, под ред. Владимира Колосова и Александра Володина. М.: ИГРАН.

Герасименко, Татьяна и Ирина Филимонова. 2011. Оренбургско-казахстанское порубежье: историкоэтнографический и этногеографический аспекты. Оренбург: Оренбургский гос. университет.

Голунов, Сергей. 2002. «Россия - Казахстан: дилемма “безопасность - сотрудничество" в трансграничных взаимоотношениях». Центральная Азия и Кавказ 4:66-78.

Голунов, Сергей. 2005. «Российско-казахстанская граница: история формирования». Вестник Волгоградского государственного университета. Сер. 4: История. Регионоведение. Международные отношения 10:68-87.

Горюнова, Екатерина. 2012. «Крымский регион в контексте теории рубежной коммуникации» С. 214-221 в Вопросы развития Крыма. Вып. 16, Крымское региональное сообщество: генезис, современное состояние, перспективы: Сборник статей. Симферополь: Сонат. 
Гудков, Лев, Борис Дубин и Алексей Левинсон. 2009. «Фоторобот российского обывателя». Мир России. Социология. Этнология 2:22-33.

Дятлов, Виктор. 2000. «Миграция китайцев и дискуссия о “Желтой опасности” в дореволюционной России». Вестник Евразии 1:63-89.

Задорин, Игорь. 2018. «Регионы “рубежа": территориальная идентичность и восприятие “особости"». Полития 2(89):102-136. doi:10.30570/2078-5089-2018-89-2-102-136.

Зотова, Мария, Антон Гриценко и Александр Себенцов. 2018. «Повседневная жизнь в российском пограничье: мотивы и факторы трансграничных практик». Мир России 4:56-77. doi:10.17323/1811-038X-2018-27-4-56-77.

Каганский, Владимир. 2000. «Украина: география и судьба страны (теоретико-географические этюды). Неприкосновенный запас 1(9):9-15.

Коллиер, Пол. 2016. Исход. Как миграция изменяет наш мир. М.: Изд-во Института Гайдара.

Колосов, Владимир, ред. 2018. Российское пограничье: вызовы соседства. М.: ИП Матушкина и. и.

Колосов, Владимир и Ольга Вендина, ред. 2011. Российско-украинское пограничье: двадцать лет разделенного единства. М.: Новый хронограф.

Колосов, Владимир и Александр Володин, ред. 2016. Российское пограничье: социально-политические и инфраструктурные проблемы. М.: ИГРАН.

Колосов, Владимир, Мария Зотова, Федор Попов, Антон Гриценко и Александр Себенцов. 2018а. «Постсоветское пограничье России между Востоком и Западом (анализ политического дискурса). Часть I. “Глядя на Запад"». Полис. Политические исследования 3:42-59. doi:10.17976/jpps/2018.03.04.

Колосов, Владимир, Мария Зотова, Федор Попов, Антон Гриценко и Александр Себенцов. 20186. «Постсоветское пограничье России между Востоком и Западом (анализ политического дискурса). Часть II. “Глядя на Восток"». Полис. Политические исследования 5:57-69. doi:10.17976/jpps/2018.05.06.

Лантух, Наталья. 2012. "0б “островной” направленности крымской региональной идентичности». С. 257-268 в Вопросы развития Крыма. Вып. 16, Крымское региональное сообщество: генезис, современное состояние, перспективы: Сборник статей. Симферополь: Сонат.

Ларин, Виктор. 2002. «Периферия "сверхдержав": Дальний Восток России в российско-китайских, российско-американских и российско-японских отношениях на рубеже веков». Вестник Дальневосточного отделения РАН 1:3-16.

Ларин, Виктор. 2008. «Межрегиональное взаимодействие России и Китая в начале XXI века: опыт, проблемы, перспективы». Проблемы Дальнего Востока 2:40-53.

Левада, Юрий. 1999. «Человек недовольный: протест и терпение». Мониторинг общественного мнения 6(44):7-13.

Левада, Юрий. 2000. «“Человек лукавый”: двоемыслие по-российски». Мониторинг общественного мнения: экономические и социальные перемены 1:19-27.

Левинсон, Алексей. 2007. «0ткрытые групповые дискуссии как метод прикладных социологических исследований». Вестник общественного мнения 6(92):45-54.

Магун, Владимир, Леокадия Дробижева и Игорь Кузнецов, ред. 2006. Гражданские, этнические и религиозные идентичности в современной России. М.: Ин-т Социологии РАН.

Макарычев, Андрей. 2008. «Безопасность и возвращение политического: критические дебаты в Европе». Индекс безопасности 4(87):25-40.

Мкртчян, Никита В. 2017. «Миграция молодежи из малых городов России». Мониторинг общественного мнения: экономические и социальные перемены 1(137):225-242. doi:10.14515/monitoring.2017.1.15.

Морачевская, Кира и Михаил Карпенко. 2018. «Влияние евразийской интеграции на экономическое взаимодействие в российско-белорусском и российско-казахстанском приграничье». Региональные исследования 3:92-100.

Морозов, Вячеслав. 2011. «Безопасность как форма политического: о секьюритизации и политизации». Полис. Политические исследования 3:24-35. 
Попов, Федор. 2012. География сецессионизма в современном мире. М.: Новый хронограф.

Рибер, Альфред. 2004. «Меняющиеся концепции и конструкции фронтира: сравнительно-исторический подход». С. 199-223 в Новая имперская история постсоветского пространства: Сборник статей, под ред. Ильи Герасимова, Сергея Глебова, Александра Каплуновского, Марины Могильнер и Александра Семенова. Казань: Центр исследований национализма и империи.

Рыжова, Наталья и Наталья Симутина. 2007. «Российско-китайская граница: отчужденная - сосуществующая - взаимозависимая». Полития 3(46):100-114.

Свинчукова, Елена. 2011. «Автопортреты русских и казахов (анализ образа “Я” в русской и казахской культурах)». Мир науки, культуры, образования 4(29):119-124.

Сень, Дмитрий. 2008. «Воображаемая география и имперский дискурс: практики Российской империи в Крыму и на Северном Кавказе в конце XVIII - начале XIX в.». Этнографическое обозрение 3:146-160.

Снежкова, Ирина. 2013. «Трансформация этнической идентичности в современной Украине (Киев, Крым. 2005-2011 гг.)». С. 222-240 в Трансформация этнической идентичности в России и в Украине в постсоветский период: Сборник статей, под ред. Ирины Снежковой. М.: ИЭА РАН.

Ткач, Ольга. 2010. «Мимоза, море и мандарины, или Один год из жизни российско-абхазкой границы». Laboratorium: журнал социальных исследований 1:274-283.

Хвощев, Владимир, ред. 2001. Границы безопасности и безопасность границ. Челябинск: Издво ЮУрГУ.

Шевчук, Александр, ред. 2006. Административно-территориальное устройство Крыма в документах и картографических образах XVIII-XXI вв. Симферополь: СФ НИСИ; ВГМИ «Таврия».

Agnew, John. 2005. "Sovereignty Regimes: Territoriality and State Authority in Contemporary World Politics." Annals of the Association of American Geographers 95(2):437-461. doi:10.1111/ j.1467-8306.2005.00468.x.

Agnew, John. 2009. Globalization and Sovereignty. Lanham, MD: Rowman and Littlefield.

Almond, Gabriel, and Sidney Verba. [1963] 1989. The Civic Culture: Political Attitudes and Democracy in Five Nations. Newbury Park, CA: SAGE.

Amilhat-Szary, Anna-Laure, and Frédéric Giraut, eds. 2015. Borderities and the Politics of Contemporary Mobile Borders. Basingstoke, UK: Palgrave Macmillan.

Andersen, Dorte Jagetić. 2013. "Exploring the Concept of (Un)familiarity: (Un)familiarity in Border Practices and Identity-Formation at the Slovenian-Croatian Border on Istria." European Planning Studies 21(1):42-57. doi:10.1080/09654313.2012.716238.

Balibar, Etienne. 2009. "Europe as Borderland." Environment and Planning D: Society and Space 27(2):190-215. doi:10.1068/d13008.

Balzacq, Tierry. 2005. "The Three Faces of Securitization: Political Agency, Audience and Context." European Journal of International Relations 11(2):171-201. doi:10.1177/1354066105052960.

Balzacq, Tierry, ed. 2010. Securitization Theory: How Security Problems Emerge and Dissolve. London: Routledge. doi:10.4324/9780203868508.

Balzacq, Tierry, Sarah Léonard, and Jan Ruzicka. 2016. "'Securitization' Revisited: Theory and Cases." International Relations 30(4):494-531. doi:10.1177/0047117815596590.

Biersteker, Thomas, and Cynthia Weber. 1996. "Introduction: The Social Construction of State Sovereignty." Pp. 1-21 in State Sovereignty as Social Construct, ed. by Thomas Biersteker and Cynthia Weber. Cambridge: Cambridge University Press.

Bigo, Didier. 2000. "When Two Become One: Internal and External Securitisations in Europe." Pp. 171-204 in International Relations Theory and the Politics of European Integration, ed. by Morten Kelstrup and Michael Williams. London: Routledge.

Billington, Ray A., and Martin Ridge. 1982. Westward Expansion: A History of the American Frontier. New York: Macmillan.

Brambilla, Chiara, Jussi Laine, James W. Scott, and Gianluca Bocchi, eds. 2015. Borderscaping: Imaginations and Practices of Border Making. Farnham, UK: Ashgate. 
Brunet-Jailly, Emmanuel, ed. 2007. Borderlands: Comparing Border Security in North America and Europe. Ottawa: University of Ottawa Press.

Buzan, Barry, and Lene Hansen. 2009. The Evolution of International Security Studies. Cambridge: Cambridge University Press.

Buzan, Barry, Ole Wæver, and Jaap de Wilde. 1998. Security: A New Framework for Analysis. Boulder, CO: Lynne Rienner.

Campbell, David. 1998. Writing Security: United States Foreign Policy and the Politics of Identity. Minneapolis: University of Minnesota Press.

Collective, C. A. S. E. 2006. "Critical Approaches to Security in Europe: A Networked Manifesto." Security Dialogue 37(4):443-487. doi:10.1177/0967010606073085.

Creswell, John W. 2014. Research Design: Qualitative, Quantitative, and Mixed Methods Approaches. Thousand Oaks, CA: Sage Publications.

Dillon, Michael, and Andrew Neal, eds. 2008. Foucault on Politics, Security and War. London: Palgrave Macmillan.

Elden, Stuart. 2006. "Contingent Sovereignty, Territorial Integrity and the Sanctity of Borders." SAIS Review of International Affairs 26(1):11-24. doi:10.1353/sais.2006.0008.

Fregonese, Sara. 2012. “Urban Geopolitics 8 Years On: Hybrid Sovereignties, the Everyday, and Geographies of Peace." Geography Compass 6(5):290-303. doi:10.1111/j.1749-8198.2012.00485.x.

Gibbs, Anita. 1997. “Focus Groups.” Social Research Update 19(8):1-8.

Guzzini, Stefano, and Dietrich Jung, eds. 2003. Contemporary Security Analysis and Copenhagen Peace Research. London: Routledge.

Huysmans, Joris-Karl. 2004. "Minding Exceptions: Politics of Insecurity and Liberal Democracy." Contemporary Political Theory 3(3):321-341. doi:10.1057/palgrave.cpt.9300137.

Johnson, Corey, Reece Jones, Anssi Paasi, Louise Amoore, Alison Mountz, Mark Salter, and Chris Rumford. 2011. "Interventions on Rethinking 'the Border' in Border Studies." Political Geography 30(2):61-69. doi:10.1016/j.polgeo.2011.01.002.

Konrad, Victor. 2015. "Towards a Theory of Borders in Motion." Journal of Borderlands Studies 30(1):1-17. doi:10.1080/08865655.2015.1008387.

Laine, Jussi. 2007. "Incommodious Border? Rethinking the Function of the Finish-Russian Border." Fennia: International Journal of Geography 185(1):49-62.

Laine, Jussi, Illka Liikanen, and James Scott, eds. 2018. Post-Cold War Borders: Reframing Political Space in Eastern Europe. London: Routledge.

Manners, Ian. 2013. "European [Security] Union: Bordering and Governing a Secure Europe in a Better World?" Global Society 27(3):398-416. doi:10.1080/13600826.2013.790791.

McDonald, Matt. 2008. "Securitization and the Construction of Security." European Journal of International Relations 14(4):563-587. doi:10.1177/1354066108097553.

Newman, David, and Anssi Paasi. 1998. "Fences and Neighbours in the Postmodern World: Boundary Narratives in Political Geography." Progress in Human Geography 22(2):186-207. doi:10.1191/030913298666039113.

Osgood, Charles E., George J. Suci, and Percy H. Tannenbaum. 1961. The Measurement of Meaning. Urbana: University of Illinois Press.

ó Tauthail, Gearóid. 1996. Critical Geopolitics: The Politics of Writing Global Space. London: Routledge.

Paasi, Anssi. 1999. "Boundaries as Social Practice and Discourse: The Finnish-Russian Border." Regional Studies 33(7):669-680. doi:10.1080/00343409950078701.

Paasi, Anssi, and Eeva-Kaisa Prokkola. 2008. “Territorial Dynamics, Cross-Border Work and Everyday Life in the Finnish-Swedish Border Area." Space and Polity 12(1):13-29. doi:10.1080/13562570801969366.

Parker, Noel, and Nick Vaughan-Williams. 2012. "Critical Border Studies: Broadening and Deepening the 'Lines in the Sand' Agenda." Geopolitics 17(4):727-733. doi:10.1080/14650045.2012.706 111. 
Paul, Regine, Marc Mölders, Alfons Bora, Michael Huber, and Peter Münte, eds. 2017. Society, Regulation and Governance: New Modes of Shaping Social Change? Northampton, MA: Edward Elgar Publishing.

Prokkola, Eeva-Kaisa. 2018. "Geopolitics of Border Securitization: Sovereignty, Nationalism and Solidarity in Asylum Reception in Finland." Geopolitics. doi:10.1080/14650045.2018. 1520213.

Rumelili, Bahar. 2004. "Constructing Identity and Relating to Difference: Understanding the EU's Mode of Differentiation." Review of International Studies 30(1):27-47. doi:10.1017/ S0260210504005819.

Rumford, Chris, ed. 2008. Citizens and Borderwork in Contemporary Europe. London: Routledge.

Salter, Mark B., and Genevieve Piché. 2011. "The Securitization of the US-Canada Border in American Political Discourse." Canadian Journal of Political Science/Revue canadienne de science politique 44(4):929-951. doi:10.1017/S0008423911000813.

Scott, James Wesley, and Henk van Houtum. 2009. "Reflections on EU Territoriality and the 'Bordering' of Europe." Political Geography 28(5):271-273. doi:10.1016/j.polgeo.2009.04.002.

Stewart, David W., Prem N. Shamdasani, and Dennis W. Rook. 2009. “Group Depth Interviews: Focus Group." Pp. 589-616 in The SAGE Handbook of Applied Social Research Methods, 2nd ed., ed. by Leonard Bickman and Debra J. Rog. Los Angeles: SAGE.

Stritzel, Holger. 2007. "Towards a Theory of Securitization: Copenhagen and Beyond." European Journal of International Relations 13(3):357-383. doi: 10.1177/1354066107080128.

Van Houtum, Henk, and Roose Pijpers. 2007. “The European Union as a Gated Community: Two Faced Border and Immigration Regime of the EU." Antipode: A Radical Journal of Geography 39(2):291-309. doi:10.1111/j.1467-8330.2007.00522.x.

Vaughan-Williams, Nick. 2015. Europe's Border Crisis: Biopolitical Security and Beyond. New York: 0xford University Press.

Walker, Robert B. J. 1990. "Security, Sovereignty, and the Challenge of World Politics." Alternatives 15(1):3-27.

Zhurzhenko, Tatiana. 2010. Borderlands into Bordered Lands: Geopolitics of Identity in Post-Soviet Ukraine. Stuttgart, Germany: Ibidem-Verlag.

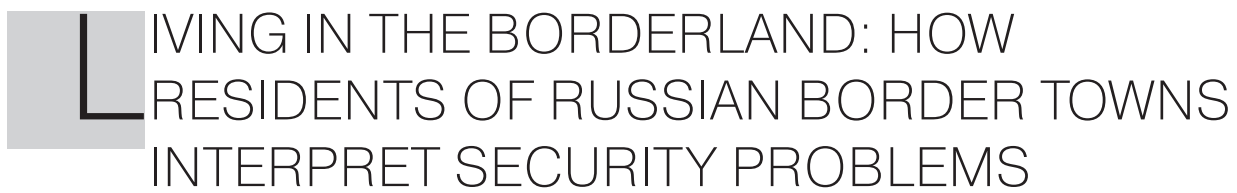

\section{Olga Vendina}

Olga Vendina, Laboratory for Geopolitical Studies, Institute of Geography, Russian Academy of Sciences. Address for correspondence: Staromonetnyi per., 29, Moscow, 119017, Russia.0.vendina@gmail.com.

Research for this article was conducted at the Institute of Geography RAS, with funding from the Russian Sciences Foundation, research project N 14-18-03621 ("The Russian Borderland: Challenges of Neighborhood"). The analysis component of research was conducted with funding from the Russian Academy of Sciences, project N 0148-2019-0008 ("The Problems and Development Prospects for Russia within the Context of Uneven Domestic Territorial Conditions and Global Instability"). 
The article proposes looking at the problem of state border security through the eyes of Russian border-town residents. Based on field research, the article examines what residents perceive to be threats and how they understand protections against those threats. The conceptual framework of the analysis is securitization theory, proposed in the late 1990s by members of the Copenhagen school of international studies and critically reconsidered in the last two decades. The article aims to identify the similarities and differences between everyday understandings of security in different border zones of Russia and between residents' perception of their roles in maintaining security. The study suggests possible explanations for the observed variability, proceeding from the specifics of local sociocultural, political, and spatial contexts. The comparative analysis involves the towns of Armiansk, Dzhankoi, Troitsk, and Zabaikal'sk, all of which are situated in immediate proximity to the state border. The selection of these four towns was determined by fundamentally different conditions at the corresponding parts of the Russian border: (a) the nonrecognized conflict border between Russia and Ukraine in Crimea; (b) the open border with Kazakhstan in Chelyabinsk Oblast; and (c) the state border with China in Zabaikal'skii Krai. The first section of the article analyzes residents' attitudes to the problem of open/closed borders in the context of security for local communities. The second section considers the factors influencing people's opinions, such as ethnic and cultural stereotypes, life context (urban area), and perceptions of the home state and of the neighboring country. The conclusion discusses discrepancies between state priorities and the interests of local residents caused by differing interpretations of security in the border zone.

Keywords: Borderlands; State; National Security; Securitization; Border Towns; Identity; Cultural Distinctiveness

\section{REFERENCES}

Agnew, John. 2005. "Sovereignty Regimes: Territoriality and State Authority in Contemporary World Politics." Annals of the Association of American Geographers 95(2):437-461. doi:10.1111/ j.1467-8306.2005.00468.x.

Agnew, John. 2009. Globalization and Sovereignty. Lanham, MD: Rowman and Littlefield.

Almond, Gabriel, and Sidney Verba. [1963] 1989. The Civic Culture: Political Attitudes and Democracy in Five Nations. Newbury Park, CA: SAGE.

Amilhat-Szary, Anna-Laure, and Frédéric Giraut, eds. 2015. Borderities and the Politics of Contemporary Mobile Borders. Basingstoke, UK: Palgrave Macmillan.

Andersen, Dorte Jagetić. 2013. “Exploring the Concept of (Un)familiarity: (Un)familiarity in Border Practices and Identity-Formation at the Slovenian-Croatian Border on Istria." European Planning Studies 21(1):42-57. doi:10.1080/09654313.2012.716238.

Balibar, Etienne. 2009. "Europe as Borderland." Environment and Planning D: Society and Space 27(2):190-215. doi:10.1068/d13008.

Balzacq, Tierry. 2005. “The Three Faces of Securitization: Political Agency, Audience and Context." European Journal of International Relations 11(2):171-201. doi:10.1177/1354066105052960.

Balzacq, Tierry, ed. 2010. Securitization Theory: How Security Problems Emerge and Dissolve. London: Routledge. doi:10.4324/9780203868508.

Balzacq, Tierry, Sarah Léonard, and Jan Ruzicka. 2016. "'Securitization' Revisited: Theory and Cases." International Relations 30(4):494-531. doi:10.1177/0047117815596590.

Bel'skii, Aleksandr. 2009. "Administrativno-territorial'noe ustroistvo Kryma: 200 let istorii." Kul'tura narodov Prichernomor'ia 155:73-77.

Biersteker, Thomas, and Cynthia Weber. 1996. "Introduction: The Social Construction of State Sovereignty." Pp. 1-21 in State Sovereignty as Social Construct, ed. by Thomas Biersteker and Cynthia Weber. Cambridge: Cambridge University Press. 
Bigo, Didier. 2000. "When Two Become One: Internal and External Securitisations in Europe." Pp. 171-204 in International Relations Theory and the Politics of European Integration, ed. by Morten Kelstrup and Michael Williams. London: Routledge.

Billé, Franck. 2014. “Sovremennost' v prostranstvennom izmerenii: 0tkrytye rynki, germetichnost' $i$ vertikal'nost' v dvukh prigranichnykh gorodakh Rossii i Kitaia." Ekonomicheskaia sotsiologiia 15(2):76-95.

Billington, Ray A., and Martin Ridge. 1982. Westward Expansion: A History of the American Frontier. New York: Macmillan.

Bogaturov, Aleksei, red. 2010. Sovremennaia mirovaia politika: Prikladnoi analiz. Moscow: Aspekt Press.

Brambilla, Chiara, Jussi Laine, James W. Scott, and Gianluca Bocchi, eds. 2015. Borderscaping: Imaginations and Practices of Border Making. Farnham, UK: Ashgate.

Brednikova, Olga. 2008. "Prigranich'e kak sotsial'nyi fenomen (napravleniia sotsiologicheskoi kontseptutsalizatsii)." Vestnik Sankt-Peterburgskogo universiteta. Ser. 12: Sotsiologiia 4:492-497.

Brednikova, Olga, and Viktor Voronkov, eds. 1992. Kochuiushchie granitsy. Saint Petersburg: TsNSI.

Brunet-Jailly, Emmanuel, ed. 2007. Borderlands: Comparing Border Security in North America and Europe. Ottawa: University of Ottawa Press.

Buzan, Barry, and Lene Hansen. 2009. The Evolution of International Security Studies. Cambridge: Cambridge University Press.

Buzan, Barry, Ole Wæver, and Jaap de Wilde. 1998. Security: A New Framework for Analysis. Boulder, C0: Lynne Rienner.

Campbell, David. 1998. Writing Security: United States Foreign Policy and the Politics of Identity. Minneapolis: University of Minnesota Press.

Collective, C. A. S. E. 2006. "Critical Approaches to Security in Europe: A Networked Manifesto." Security Dialogue 37(4):443-487. doi:10.1177/0967010606073085.

Collier, Paul. 2016. Iskhod: Kak migratsiia izmeniaet nash mir. Moscow: Izd. Instituta Gaidara.

Creswell, John W. 2014. Research Design: Qualitative, Quantitative, and Mixed Methods Approaches. Thousand Oaks, CA: Sage Publications.

Diatlov, Viktor. 2000. “Migratsiia kitaitsev i diskussiia o 'Zheltoi opasnosti' v dorevoliutsionnoi Rossii." Vestnik Evrazii 1:63-89.

Dillon, Michael, and Andrew Neal, eds. 2008. Foucault on Politics, Security and War. London: Palgrave Macmillan.

Elden, Stuart. 2006. "Contingent Sovereignty, Territorial Integrity and the Sanctity of Borders." SAIS Review of International Affairs 26(1):11-24. doi:10.1353/sais.2006.0008.

Fregonese, Sara. 2012. “Urban Geopolitics 8 Years On: Hybrid Sovereignties, the Everyday, and Geographies of Peace." Geography Compass 6(5):290-303. doi:10.1111/j.1749-8198.2012.00485.x.

Gerasimenko, Tat'iana. 2016. “Transgranichnye regiony na postsovetskom prostranstve: Spetsifika, problemy, perspektivy." Pp. 44-54 in Rossiiskoe pogranich'e: Sotsial'no-politicheskie i infrastrukturnye problemy, ed. by Vladimir Kolosov and Aleksandr Volodin. Moscow: IGRAN.

Gerasimenko, Tat'iana, and Irina Filimonova. 2011. Orenburgsko-kazakhstanskoe porubezh'e: Istorikoetnograficheskii i etnogeograficheskii aspekty. Orenburg, Russia: Orenburgskii gos. universitet.

Gibbs, Anita. 1997. "Focus Groups." Social Research Update 19(8):1-8.

Golunov, Sergei. 2002. "Rossiia-Kazakhstan: Dilemma 'bezopasnost'-sotrudnichestvo' v transgranichnykh vzaimootnosheniiakh." Tsentral'naia Aziia i Kavkaz 4:66-78.

Golunov, Sergei. 2005. "Rossiisko-kazakhstanskaia granitsa: Istoriia formirovaniia." Vestnik Volgogradskogo gosudarstvennogo universiteta. Ser. 4: Istoriia. Regionovedenie. Mezhdunarodnye otnosheniia 10:68-87.

Goriunova, Ekaterina. 2012. "Krymskii region v kontekste teorii rubezhnoi kommunikatsii." Pp. 214-221 in Voprosy razvitiia Kryma. Vol. 16, Krymskoe regional'noe soobshchestvo: genezis, sovremennoe sostoianie, perspektivy. Simferopol': Izd. "Sonat."

Gudkov, Lev, Boris Dubin, and Aleksei Levinson. 2009. "Fotorobot rossiiskogo obyvatelia." Mir Rossii: Sotsiologiia, Etnologiia 2:22-33. 
Guzzini, Stefano, and Dietrich Jung, eds. 2003. Contemporary Security Analysis and Copenhagen Peace Research. London: Routledge.

Huysmans, Joris-Karl. 2004. "Minding Exceptions: Politics of Insecurity and Liberal Democracy." Contemporary Political Theory 3(3):321-341. doi:10.1057/palgrave.cpt.9300137.

Johnson, Corey, Reece Jones, Anssi Paasi, Louise Amoore, Alison Mountz, Mark Salter, and Chris Rumford. 2011. "Interventions on Rethinking 'the Border' in Border Studies." Political Geography 30(2):61-69. doi:10.1016/j.polgeo.2011.01.002.

Kaganskii, Vladimir. 2000. “Ukraina: Geografiia i sud'ba strany (teoretiko-geograficheskie etiudy)." Neprikosnovennyi zapas 1(9):9-15.

Khvoshchev, Vladimir, ed. 2001. Granitsy bezopasnosti i bezopasnost' granits. Chelyabinsk, Russia: Izd. IuUrGU.

Kolosov, Vladimir, ed. 2018. Rossiiskoe pogranich'e: Vyzovy sosedstva. Moscow: IP Matushkina I. I.

Kolosov, Vladimir, and Olga Vendina, eds. 2011. Rossiisko-ukrainskoe pogranich'e: Dvadtsat' let razdelennogo edinstva. Moscow: Novyi khronograf.

Kolosov, Vladimir, and Aleksandr Volodin, eds. 2016. Rossiiskoe pogranich'e: Sotsial'no-politicheskie $i$ infrastrukturnye problemy. Moscow: IGRAN.

Kolosov, Vladimir, Mariia Zotova, Fedor Popov, Anton Gritsenko, and Aleksandr Sebentsov. 2018a. “Postsovetskoe pogranich'e Rossii mezhdu Vostokom i Zapadom (analiz politicheskogo diskursa). Chast' I. 'Gliadia na Zapad.'" Polis: Politicheskie issledovaniia 3:42-59. doi:10.17976/ jpps/2018.03.04.

Kolosov, Vladimir, Mariia Zotova, Fedor Popov, Anton Gritsenko, and Aleksandr Sebentsov. 2018b. "Postsovetskoe pogranich'e Rossii mezhdu Vostokom i Zapadom (analiz politicheskogo diskursa). Chast' II. 'Gliadia na Vostok.'” Polis: Politicheskie issledovaniia 5:57-69. doi:10.17976/ jpps/2018.05.06.

Konrad, Victor. 2015. "Towards a Theory of Borders in Motion." Journal of Borderlands Studies 30(1):1-17. doi:10.1080/08865655.2015.1008387.

Laine, Jussi. 2007. "Incommodious Border? Rethinking the Function of the Finish-Russian Border." Fennia: International Journal of Geography 185(1):49-62.

Laine, Jussi, Illka Liikanen, and James Scott, eds. 2018. Post-Cold War Borders: Reframing Political Space in Eastern Europe. London: Routledge.

Lantukh, Natal'ia. 2012. “Ob 'ostrovnoi' napravlennosti krymskoi regional'noi identichnosti." Pp. 257-268 in Voprosy razvitiia Kryma. Vol. 16, Krymskoe regional'noe soobshchestvo: Genezis, sovremennoe sostoianie, perspektivy. Simferopol': Izd. "Sonat."

Larin, Viktor. 2002. “Periferiia 'sverkhderzhav': Dal'nii Vostok Rossii v rossiisko-kitaiskikh, rossiisko-amerikanskikh i rossiisko-iaponskikh otnosheniiakh na rubezhe vekov." Vestnik Dal'nevostochnogo otdeleniia RAN 1:3-16.

Larin, Viktor. 2008. “Mezhregional'noe vzaimodeistvie Rossii i Kitaia v nachale XXI veka: Opyt, problemy, perspektivy." Problemy Dal'nego Vostoka 2:40-53.

Levada, Iurii. 1999. “Chelovek nedovol'nyi: Protest i terpenie." Monitoring obshchestvennogo mneniia 6(44):7-13.

Levada, Iurii. 2000. "'Chelovek lukavyi': Dvoemyslie po-rossiiski." Monitoring obshchestvennogo mneniia: Ekonomicheskie i sotsial'nye peremeny 1:19-27.

Levinson, Aleksei. 2007. “0tkrytye gruppovye diskussii kak metod prikladnykh sotsiologicheskikh issledovanii." Vestnik obshchestvennogo mneniia 6(92):45-54.

Magun, Vladimir, Leokadiia Drobizheva, and Igor' Kuznetsov, eds. 2006. Grazhdanskie, etnicheskie $i$ religioznye identichnosti v sovremennoi Rossii. Moscow: In-t Sotsiologii RAN.

Makarychev, Andrei. 2008. “Bezopasnost' i vozvrashchenie politicheskogo: Kriticheskie debaty v Evrope." Indeks bezopasnosti 4(87):25-40.

Manners, Ian. 2013. "European [Security] Union: Bordering and Governing a Secure Europe in a Better World?" Global Society 27(3):398-416. doi:10.1080/13600826.2013.790791.

McDonald, Matt. 2008. "Securitization and the Construction of Security." European Journal of International Relations 14(4):563-587. doi:10.1177/1354066108097553. 
Mkrtchian, Nikita. 2017. “Migratsiia molodezhi iz malykh gorodov Rossii." Monitoring obshchestvennogo mneniia: Ekonomicheskie i sotsial'nye peremeny 1(137):225-242. doi:10.14515/monitoring.2017.1.15.

Morachevskaia, Kira, and Mikhail Karpenko. 2018. “Vliianie evraziiskoi integratsii na ekonomicheskoe vzaimodeistvie v rossiisko-belorusskom i rossiisko-kazakhstanskom prigranich'e." Regional'nye issledovaniia 3:92-100.

Morozov, Viacheslav. 2011. “Bezopasnost' kak forma politicheskogo: 0 sek'iuritizatsii i politizatsii." Polis: Politicheskie issledovaniia 3:24-35.

Newman, David, and Anssi Paasi. 1998. "Fences and Neighbours in the Postmodern World: Boundary Narratives in Political Geography." Progress in Human Geography 22(2):186-207. doi:10.1191/030913298666039113.

Osgood, Charles E., George J. Suci, and Percy H. Tannenbaum. 1961. The Measurement of Meaning. Urbana: University of Illinois Press.

ó Tauthail, Gearóid. 1996. Critical Geopolitics: The Politics of Writing Global Space. London: Routledge.

Paasi, Anssi. 1999. "Boundaries as Social Practice and Discourse: The Finnish-Russian Border." Regional Studies 33(7):669-680. doi:10.1080/00343409950078701.

Paasi, Anssi, and Eeva-Kaisa Prokkola. 2008. “Territorial Dynamics, Cross-Border Work and Everyday Life in the Finnish-Swedish Border Area." Space and Polity 12(1):13-29. doi:10.1080/13562570801969366.

Parker, Noel, and Nick Vaughan-Williams. 2012. "Critical Border Studies: Broadening and Deepening the 'Lines in the Sand' Agenda." Geopolitics 17(4):727-733. doi:10.1080/14650045.2012.706 111.

Paul, Regine, Marc Mölders, Alfons Bora, Michael Huber, and Peter Münte, eds. 2017. Society, Regulation and Governance: New Modes of Shaping Social Change? Northampton, MA: Edward Elgar Publishing.

Popov, Fedor. 2012. Geografiia setsessionizma v sovremennom mire. Moscow: Novyi khronograf.

Prokkola, Eeva-Kaisa. 2018. "Geopolitics of Border Securitization: Sovereignty, Nationalism and Solidarity in Asylum Reception in Finland." Geopolitics. doi:10.1080/14650045.2018. 1520213.

Rieber, Alfred. 2004. “Meniaiushchiesia kontseptsii i konstruktsii frontira: Sravnitel'no-istoricheskii podkhod." Pp. 199-223 in Novaia imperskaia istoriia postsovetskogo prostranstva, ed. by Il'ia Gerasimov, Sergei Glebov, Aleksandr Kaplunovskii, Marina Mogil'ner, and Aleksandr Semenov. Kazan', Russia: Izd. “Tsentr Issledovanii Natsionalizma i Imperii."

Rumelili, Bahar. 2004. “Constructing Identity and Relating to Difference: Understanding the EU's Mode of Differentiation." Review of International Studies 30(1):27-47. doi:10.1017/ S0260210504005819.

Rumford, Chris, ed. 2008. Citizens and Borderwork in Contemporary Europe. London: Routledge.

Ryzhova, Natal'ia, and Natalia Simutina. 2007. "Rossiisko-kitaiskaia granitsa: Otchuzhdennaia sosushchestvuiushchaia - vzaimozavisimaia." Politiia 3(46):100-114.

Salter, Mark B., and Genevieve Piché. 2011. "The Securitization of the US-Canada Border in American Political Discourse." Canadian Journal of Political Science/Revue canadienne de science politique 44(4):929-951. doi:10.1017/S0008423911000813.

Scott, James Wesley, and Henk van Houtum. 2009. "Reflections on EU Territoriality and the 'Bordering' of Europe." Political Geography 28(5):271-273. doi:10.1016/j.polgeo.2009.04.002.

Sen', Dmitrii V. 2008. "Voobrazhaemaia geografiia i imperskii diskurs: Praktiki Rossiiskoi imperii v Krymu i na Severnom Kavkaze v kontse XVIII-nachale XIX veka." Etnograficheskoe obozrenie 3:146-160.

Shevchuk, Aleksandr, ed. 2006. Administrativno-territorial'noe ustroistvo Kryma v dokumentakh $i$ kartograficheskikh obrazakh XVIII-XXI vv. Simferopol': SF NISI; VGMI “Tavriia." 
Snezhkova, Irina A. 2013. “Transformatsiia etnicheskoi identichnosti v sovremennoi Ukraine (Kiev, Krym. 2005-2011 gg.)." Pp. 222-240 in Transformatsiia etnicheskoi identichnosti v Rossii i v Ukraine $v$ postsovetskii period, ed. by. Irina A. Snezhkova. Moscow: IEA RAN.

Stewart, David W., Prem N. Shamdasani, and Dennis W. Rook. 2009. “Group Depth Interviews: Focus Group." Pp. 589-616 in The SAGE Handbook of Applied Social Research Methods, 2nd ed., ed. by Leonard Bickman and Debra J. Rog. Los Angeles: SAGE.

Stritzel, Holger. 2007. "Towards a Theory of Securitization: Copenhagen and Beyond." European Journal of International Relations 13(3):357-383. doi:10.1177/1354066107080128.

Svinchukova, Elena. 2011. “Avtoportrety russkikh i kazakhov (analiz obraza 'Ia' v russkoi i kazakhskoi kul'turakh)." Mir nauki, kultury, obrazovaniia 4(29):119-124.

Tkach, Olga. 2010. "Mimoza, more i mandariny, ili odin god iz zhizni rossiisko-abkhazkoi granitsy." Laboratorium 1:274-283.

Van Houtum, Henk, and Roose Pijpers. 2007. “The European Union as a Gated Community: Two Faced Border and Immigration Regime of the EU." Antipode: A Radical Journal of Geography 39(2):291-309. doi:10.1111/j.1467-8330.2007.00522.x.

Vaughan-Williams, Nick. 2015. Europe's Border Crisis: Biopolitical Security and Beyond. New York: 0xford University Press.

Vendina, Olga, and Vladimir Kolosov. 2007. "Partnerstvo v obkhod bar'erov." Rossiia v global'noi politike 1. https://globalaffairs.ru/number/n_8147.

Walker, Robert B. J. 1990. "Security, Sovereignty, and the Challenge of World Politics." Alternatives 15(1):3-27.

Zadorin, Igor. 2018. "Regiony 'rubezha': Territorial'naia identichnost' i vospriiatie "osobosti."' Politiia 2(89):102-136. doi:10.30570/2078-5089-2018-89-2-102-136.

Zhurzhenko, Tatiana. 2010. Borderlands into Bordered Lands: Geopolitics of Identity in Post-Soviet Ukraine. Stuttgart, Germany: Ibidem-Verlag.

Zotova, Mariia, Anton Gritsenko, and Aleksandr Sebentsov. 2018. “Povsednevnaia zhizn' v rossiiskom pogranich'e: Motivy i faktory transgranichnykh praktik." Mir Rossii 4:56-77. doi:10.17323/1811-038X-2018-27-4-56-77. 